\title{
Gabbroic enclave in intermediate ignimbrites: The youngest eruptive event in the northern Luzon Arc-Taiwan region
}

\author{
Yu-Ming Lai ${ }^{1, *}$, Yu-Yun Cho ${ }^{1}$, Hao-Yang Lee ${ }^{2}$, Dung-Han Lee ${ }^{1}$, Yoshiyuki Iizuka ${ }^{2}$, \\ and Long Xiang Quek ${ }^{1}$ \\ ${ }^{1}$ Department of Earth Sciences, National Taiwan Normal University, Taipei City, Taiwan \\ ${ }^{2}$ Institute of Earth Sciences, Academia Sinica, Taipei City, Taiwan
}

Article history:

Received 30 December 2020

Revised 26 August 2021

Accepted 7 September 2021

\section{Keywords:}

Mafic magmatic enclaves, Zircon $\mathrm{U}-\mathrm{Pb}$ geochronology, Ignimbrite, Northern Luzon Arc, Geochemistry, Shihtiping Tuff

\section{Citation:}

Lai, Y.-M., Y.-Y. Cho, H.-Y. Lee, D.-H. Lee, Y. Iizuka, and L. X Quek, 2021: Gabbroic enclave in intermediate ignimbrites: The youngest eruptive event in the northern Luzon Arc-Taiwan region. Terr. Atmos. Ocean. Sci., 32, 459-481, doi: 10.3319/TAO.2021.09.07.02

\begin{abstract}
The white ignimbrite layer on top of volcanic sequences in the Coastal Range is the youngest eruption of the northern Luzon Arc in the Taiwan region. A gabbroic enclave was coexisting with the andesitic ignimbrite in this sequence. This study reports the dating results, textural and petrographic descriptions, and geochemical characteristics of the gabbroic enclave and andesitic breccias in the ignimbrite. Both components erupted approximately at $4 \mathrm{Ma}$, and show enrichment in large ion lithophile elements and depletion in high field strength elements, which are important island arc characteristics. Major and trace elements indicated that the andesitic magma shows larger fractionation and lower degrees of partial melting than the basaltic magma which formed the gabbroic enclaves. We suggest that three sub-stages of magmatism occur during the youngest eruption of the northern Luzon Arc at $\sim 4 \mathrm{Ma}$. In the first sub-stage, the basaltic magma generated by higher degrees of partial melting from the source rose to a shallow reservoir and cooled to build up the gabbroic wall rocks. Later, lower degrees of partial melting magma were injected into the shallow reservoir and fractionated to intermediate magma causing the second substage. The third sub-stage was activated by the recharged magma, which triggered the intermediate magma to rise along the earlier pathway and assimilated within the gabbroic wall rock. This magma eventually erupted to form the andesitic ignimbrite with gabbroic enclaves within.
\end{abstract}

\section{INTRODUCTION}

Mafic enclaves are usually present in igneous rocks that are associated with calc-alkaline igneous suites (Didier 1973). They are formed from source rock partial melting or cumulates at earlier stages of crystallization in the magma reservoir (Maury et al. 1978; Bacon 1986; Chappell et al. 1987; Dorais et al. 1990), and might provide information on the origin and evolution of magma. These mafic enclaves are well documented in volcanic occurrences such as diverse compositions of lava flows or domes. In volcanic rocks, mafic enclaves represent products of mafic magmas that have quenched in lava flows, domes, or intrusions (Eichelberger 1980; Bacon and Metz 1984; Bacon 1986; Elburg 1996; Cole et al. 2001; Martin et al. 2006; Bardelli

\footnotetext{
* Corresponding author

E-mail:ymlai@ntnu.edu.tw
}

et al. 2020). Similarly, they can coexist within the plutonic intrusions (Didier 1973; Vernon 1984; Barbarin and Didier 1991; Wiebe 1994; Arvin et al. 2004; Browne et al. 2006; Plail et al. 2018).

In arc-related volcanic rocks, studying the mafic enclaves helps reveal the mechanism of interaction between different magmas in the magma chamber (Bacon 1986; Clynne 1999; Coombs et al. 2003; Browne et al. 2006; Martin et al. 2006; Morgavi et al. 2013; Hernando et al. 2016; Plail et al.2018). The geochemical compositions and dating results of the mafic enclaves can provide information on the occurrences of syn-eruptive events and co-magmatic plutonic enclaves (Eichelberger 1980; Bacon 1986; Cole et al. 2001; Couch et al. 2001; Martin et al. 2006; Hernando et al. 2016; Plail et al. 2018).

In this study, we present a gabbroic enclave with an intermediate ignimbrite from the Shihtiping area in the 
northern Luzon arc (NLA) (Fig. 1). According to our dating results, both the gabbroic enclave and ignimbrite were formed at $4 \mathrm{Ma}$. Whole-rock major and trace element compositions from the gabbroic enclave, andesitic breccias and bombs from ignimbrite were analyzed. Based on these data, we suggest three sub-stages of magmatic processes during $\sim 4 \mathrm{Ma}$. First, gabbroic wall rocks of a magma reservoir were formed by the earlier shallow intrusion. Then, new magma was injected into this reservoir and fractionated to intermediate magma. After that, a recharged magma arose and triggered the intermediate magma to assimilate with the gabbroic wall rock and eventually erupted to form ignimbrite.

\section{GEOLOGICAL BACKGROUND}

The NLA was formed by the subduction of the South China Sea Plate beneath the western Philippine Sea Plate (Bowin et al. 1978). The northernmost part of NLA collided with the Eurasian Plate following the movement of the Philippine Sea Plate. Then, the volcanic islands were uplifted and thrusted towards eastern Taiwan to form the Coastal Range (CR) (Biq 1972; Karig 1973; Suppe 1981, 1984; Teng 1990) (Fig. 1). The volcanic rocks in the CR are divided into four volcanoes: named Yuemei, Chimei, Chengkuang'ao, and Tuluanshan, as per a detailed volcanological study (Lai and Song 2013). Previous researchers named volcanic sequences coupled with the covering limestone the Chimei Igneous Complex and Tuluanshan Formation (Teng et al. 1988; Song and Lo 1990). Chimei volcano is located in the central part of the CR with a well-exposed volcanic sequences (Song and Lo 2002; Lai and Song 2013). From bottom to top, principal lithofacies are including the lava flows and dykes (Chimei Igneous Complex), black volcanic breccias (Shihmen Volcanic Breccia), and the white ignimbrite with lots of volcanic bombs and blocks inside (Shihtiping Tuff) (Fig. 2). It's worth noting that no intrusive rocks or mafic enclaves have been mentioned in the literature from the CR.

Several researchers conducted systematically igneous whole-rock geochemical studies through the volcanic sequences, including major, trace, and $\mathrm{Sr}-\mathrm{Nd}$ isotope data (e.g., Chen 1975; Chen et al. 1990; Defant et al. 1990; Lai et al. 2008, 2017; Song 1990). According to the previous works, the geochemical variation shows incompatible element concentrations increasing and $\varepsilon \mathrm{Nd}$ values decreasing upward with the volcanic sequences, and the increasing of crustal contamination has been employed to explain such a variation (Yang 1992; Fourcade et al. 1994).

Geochronological studies of the Tuluanshan Formation used whole-rock or mineral $\mathrm{K}-\mathrm{Ar},{ }^{40} \mathrm{Ar}-{ }^{39} \mathrm{Ar}$, fission-track, and zircon U-Pb dating methods, and yielded ages from 22.2 to 4.4 Ma (Ho 1969; Juang and Bellon 1984; Richard et al. 1986; Yang et al. 1988, 1995; Lo et al. 1994; Song and Lo 2002; Shao et al. 2015; Lai et al. 2017, 2018; Geng et al. 2018). The age data showed a gradually younger and consistent age with volcanic sequences from bottom to top in each volcano (Lai et al. 2018). We can date the youngest magmatism age in the CR from the top of the Tuluanshan Formation, i.e., the Shihtiping Tuff. From the north to south, the youngest eruption stage was at $6.2 \mathrm{Ma}$ in the Yuemei volcano (K-Ar, Song 1990), 4.2 Ma in the Chimei volcano $\left({ }^{40} \mathrm{Ar}^{39} \mathrm{Ar}\right.$, Lai et al. 2017; and Zircon U-Pb, Lai et al. 2018), 4.4 Ma in the Chengkuang' ao volcano $\left({ }^{40} \mathrm{Ar}-{ }^{39} \mathrm{Ar}\right.$, Lo et al. 1994), and 8.5 Ma in the Tuluanshan volcano (Zircon U-Pb, Lai et al. 2018).

\section{ANALYTICAL METHODS}

The samples were collected from the top of the volcanic sequence (Shihtiping Tuff) of the Chimei volcano, which belongs to the central part of CR (Fig. 1). A total of five samples including four andesitic breccias (18STP02-1, 18STP03-2, 18STP03-3, and 18STP04-1) and one gabbroic enclave (18STP01-1) were collected from the ignimbrite in the Shihtiping Tuff at the Shihtiping area (Figs. 2, 3a to c). Thin sections for the petrography study were prepared by careful cutting to avoid the weathering surface. Phenocrysts and textures were examined under an optical microscope and with the point-counting method. All samples were analyzed for whole-rock major and trace elements, and three of them (18STP01-1, 18STP02-1, and 18STP03-2) were dated using the zircon U-Pb method. Additionally, sixteen samples from previous studies in the Chimei volcano were combined for discussion (Lai et al. 2017, 2018), which included four andesitic bombs in the Shihtiping Tuff, six breccias from the Shihmen Volcanic Breccia, and six dyke and lava flow samples from the Chimei Igneous Complex (Fig. 2).

\subsection{Zircon U-Pb Geochronology}

Zircon grains were separated from 3-kg sample rocks using conventional heavy liquid and magnetic techniques. Zircons were then mounted in epoxy and polished to expose their interior in the Department of Geosciences, National Taiwan University, Taipei. Based on the cathodoluminescence (CL) images taken at the Institute of Earth Sciences, Academia Sinica, Taipei, internal structures of individual magmatic zircons were identified. Zircon $\mathrm{U}-\mathrm{Pb}$ isotopic analyses were conducted using a Photon Machines Analyte G2 laser ablation system attached to an Agilent 7900s inductively coupled plasma quadrupole mass spectrometer (ICPQ-MS) at the Department of Geosciences, National Taiwan University, Taipei. The analyzing spot was $\sim 30 \mu \mathrm{m}$ in diameter and the repetition rate was $4 \mathrm{~Hz}$. Detailed analytical procedures followed those reported by Chiu et al. (2009, 2013). The common lead correction method was used, as suggested by Andersen (2002). Zircon standard GJ-1 (608.5 $\pm 0.4 \mathrm{Ma}$, Jackson et al. 2004) was used to build the 
(a)

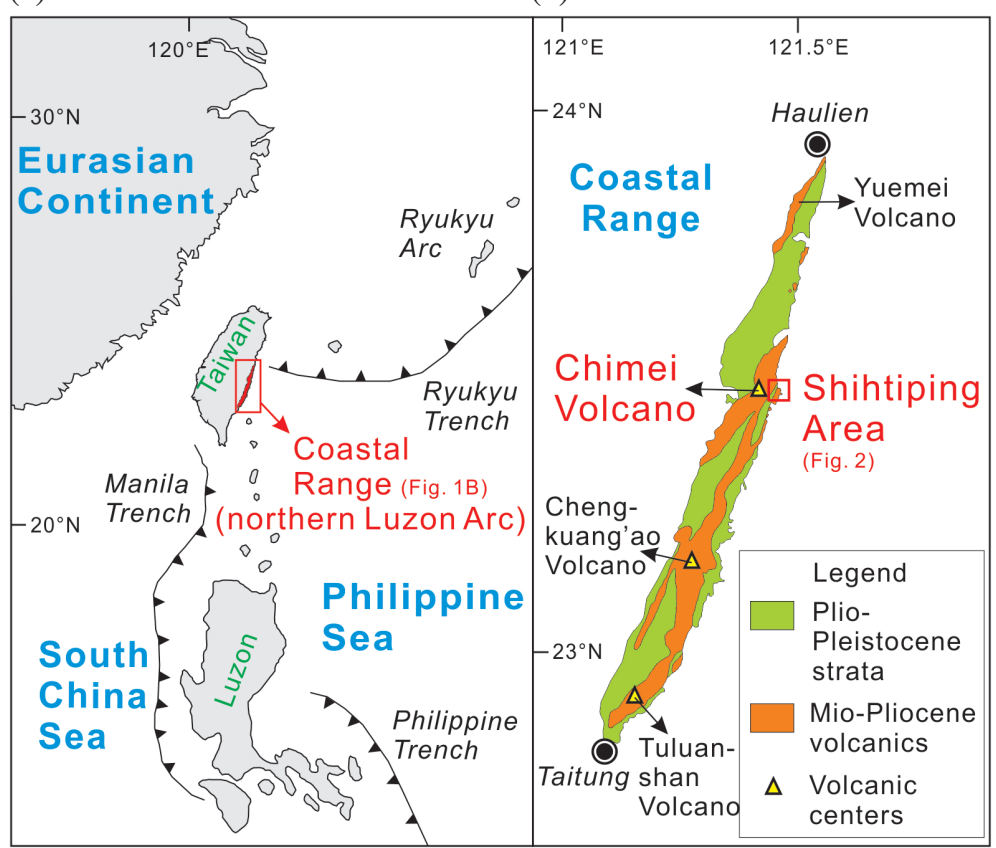

Fig. 1. (a) Simplified sketch of tectonic setting around Taiwan and the northern Luzon Arc. The rectangular region (marked in red color) shows the Coastal Range area. (b) The geological map of the Coastal Range. The red square region shows the study area, named Shihtiping, belonging to the Chimei volcano.

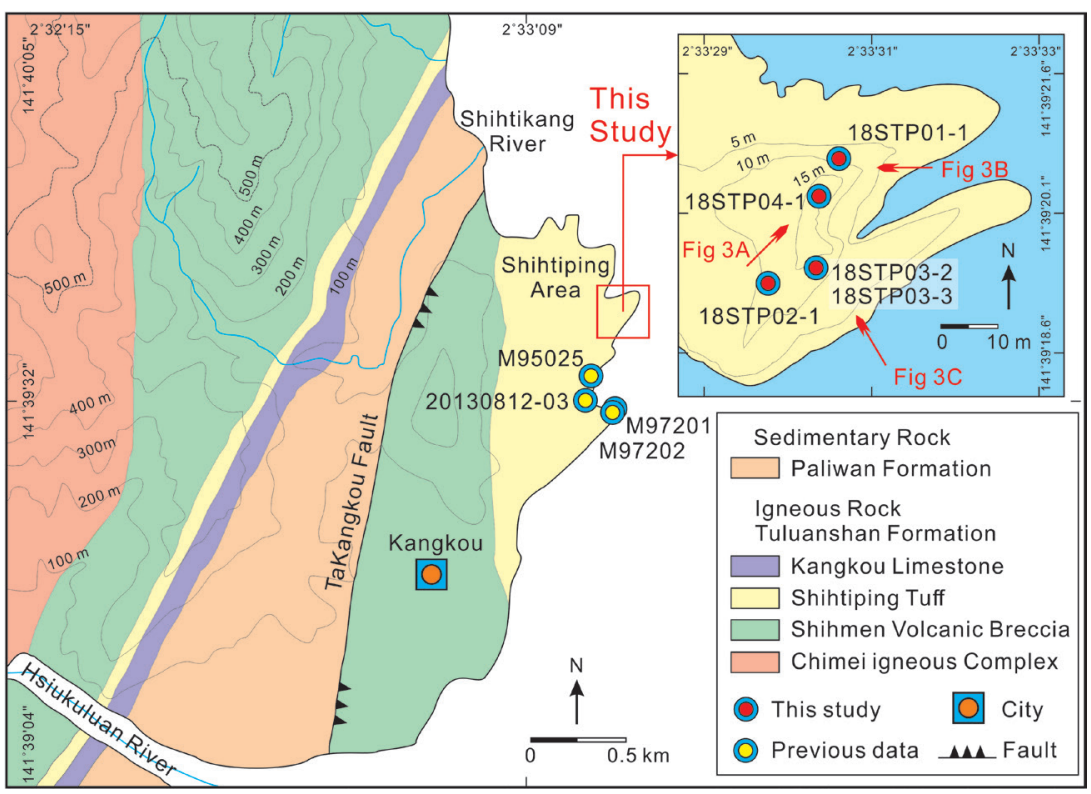

Fig. 2. The geological map of the Shihtiping area. All samples were collected from the top volcanic sequence in the Shihtiping Tuff from the Tuluanshan Formation. Some volcanic rock samples from Lai et al. $(2017,2018)$ were combined in this study and their sample localities have been marked on the map as well. 

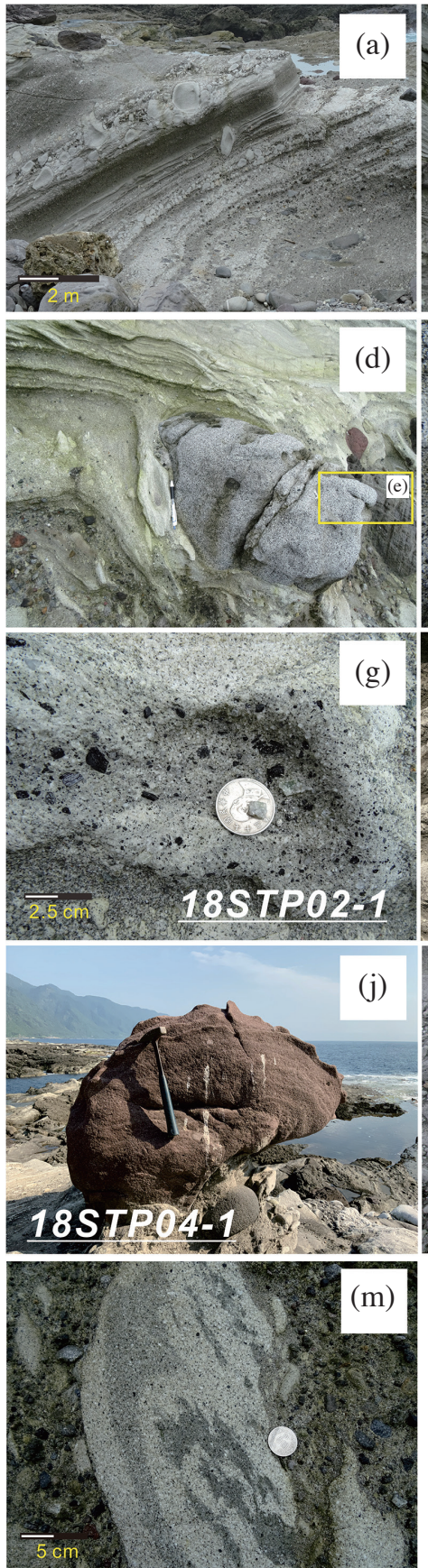
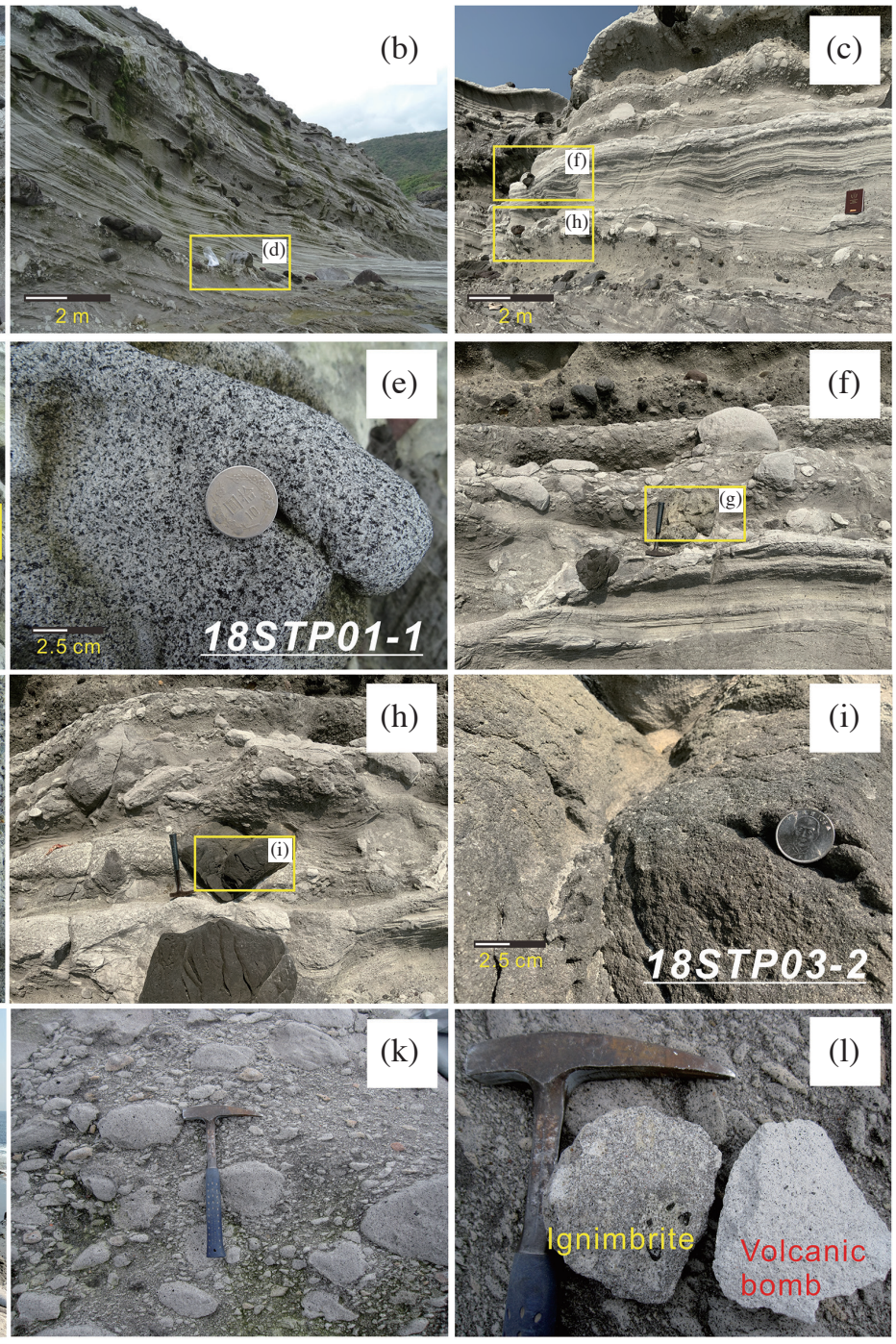

Fig. 3. Outcrop photos of the Shihtiping ignimbrite in Shihtiping area. (a) - (j) Ignimbrite layers and sample locations in this study. (e) The gabbroic enclave sample. (g) (i) (j) Andesitic volcanic breccia samples. (k) Andesitic volcanic bombs in ignimbrite. (l) Comparison between ignimbrite and volcanic bomb. (m) Magma mixing/mingling occurrence. 
calibration curves, and two referential zircons, 91500 (1065.4 \pm 0.6 Ma, Wiedenbeck et al. 1995) and Pleŝovice (337.1 + 0.4 Ma, Sláma et al. 2008), were used for assessment of age quality. In order to quantify the precision and accuracy, we analyzed the reference materials as unknown samples and got the weighted average of $91500\left({ }^{206} \mathrm{~Pb} /{ }^{238} \mathrm{U}\right.$ age $=1062 \pm 8 \mathrm{Ma}, 2 \sigma, \mathrm{MSWD}=0.2, \mathrm{n}=34 ;{ }^{207} \mathrm{~Pb} /{ }^{206} \mathrm{~Pb}$ age $=1069 \pm 8 \mathrm{Ma}, 2 \sigma, \mathrm{MSWD}=0.52, \mathrm{n}=34)$ and Pleŝovice $\left({ }^{206} \mathrm{~Pb} /{ }^{238} \mathrm{U}\right.$ age $\left.=336 \pm 3 \mathrm{Ma}, 2 \sigma, \mathrm{MSWD}=0.22, \mathrm{n}=32\right)$. The U-Th-Pb isotopic ratios, concordia diagrams, probability curves, and the weighted mean $\mathrm{U}-\mathrm{Pb}$ ages were obtained using Isoplot v. 4.15 (Ludwig 2008) software and the online program, GLITTER 4.4 (Griffin et al. 2008).

\subsection{Major and Trace Element Analyses}

Andesitic breccias and a gabbroic enclave were crushed using a jaw crusher and pulverized in agate mortars. Next, $0.5000 \pm 0.0001 \mathrm{~g}$ of sample powder and $5.0000 \pm 0.0005 \mathrm{~g}$ of flux powder (anhydrous lithium tetraborate, $\mathrm{Li}_{2} \mathrm{~B}_{4} \mathrm{O}_{7}$ ) were weighed and mixed well in the Pt-Au crucible to make fused glass disks. The concentration of the major elements were analyzed using X-ray fluorescence (XRF, Rigaku ${ }^{\circledR}$ RIX 2000) spectrometry in the Department of Geosciences, National Taiwan University, Taipei. The analytical uncertainties were generally below 5\% RSD. The loss-on-ignition (LOI) values were calculated by the weight loss percentage of samples after heating at $950^{\circ} \mathrm{C}$ for $60 \mathrm{~min}$. After the major element analyses, glass disks were crushed and dissolved in $\mathrm{HF}$ and $\mathrm{HNO}_{3}$ under heating. We further added $10 \mathrm{ppb} \mathrm{Rh}$ and $\mathrm{Bi}$ as internal standards. Trace elements were measured using an Agilent 7900s ICP-Q-MS at the Institute of Earth Sciences, Academia Sinica, Taipei. The USGS standards AGV-2, BHVO-2, and BCR-2 were used for calibration (Supplementary, Table S1), and the recommended values are from Jochum et al. (2005). Analytical uncertainties were estimated to be generally below $3 \%$ RSD, and the details are the same as reported in Lin et al. (2012).

\section{RESULTS}

\subsection{Occurrences and Petrography}

All samples were collected from the ignimbrite in the Shihtiping Tuff (Fig. 3a). The sample 18STP01-1 is a gabbroic enclave and was surrounded by ignimbrite (Figs. 3b, $\mathrm{d}$, and e) (note the sharp boundary between the enclave and ignimbrite). Samples 18STP02-1, 18STP03-2, 18STP03-3, and 18STP04-1 (Figs. 3c, f to j) were all andesitic breccias located in higher sequences as compared to the enclave sample. The sample 18STP02-1 was white and contained large amphibole crystals on the surface (Fig. 3g), whereas the samples 18STP03-2 and 18STP03-3 were dark in color with thin phenocrysts (Fig. 3i). The sample 18STP04-1 was located on the top of this sequence and was red due to thermal oxidation (Fig. 3j). Several volcanic bombs were found coexisting with the ignimbrite (Figs. 3k and 1), and we combined the volcanic bomb samples which were collected from the same sequence from previous studies for comparison (Lai et al. 2017, 2018). Some magma mixing textures were observed (Fig. $3 \mathrm{~m}$ ) near the gabbroic enclave sample (18STP01-1).

One representative sample each for the gabbroic enclave (18STP01-1) and andesitic breccia (18STP02-1) was selected for petrographic studies (Fig. 4 and Table 1). The gabbroic enclave with equigranular texture was composed of plagioclase $(\sim 72.3 \%, \sim 200-650 \mu \mathrm{m})$, amphibole $(\sim 21.7 \%$, $\sim 200-300 \mu \mathrm{m})$, pyroxene ( $2.6 \%$ orthopyroxene and $\sim 0.8 \%$ clinopyroxene, $\sim 200-450 \mu \mathrm{m})$, and Fe-Ti oxides $(\sim 2.6 \%)$ (Figs. 4a to d, and Table 1). According to the IUGS classification of the gabbroic rocks (Supplementary, Fig. S1), the enclave in this study belongs to the hornblende gabbro (Streckeisen 1976). The andesitic breccia sample shows a porphyritic texture and contains $\sim 60.2 \%$ phenocrysts (Table 1), including plagioclase $(\sim 73.2 \%, \sim 150$ - $500 \mu \mathrm{m})$, orthopyroxene $(\sim 11.6 \%, \sim 200-250 \mu \mathrm{m})$, clinopyroxene $(\sim 9.6 \%, \sim 150$ - $200 \mu \mathrm{m})$, amphibole $(\sim 3.5 \%$, 200 - $400 \mu \mathrm{m})$, and Fe-Ti oxides $(\sim 2.0 \%)$ (Figs. 4 e to h, and Table 1$)$.

\subsection{Zircon U-Pb Ages}

The representative CL images of zircons are shown in Supplementary, Fig. S2 and the analytic data are listed in Table 2. As sample 18STP02-1 showed only seven zircon grains for age dating, the data amount was considered statistically insufficient. The ages of the other two samples are presented as concordia diagrams, calculated weighted mean ${ }^{206} \mathrm{~Pb} /{ }^{238} \mathrm{U}$ ages, and probabilistic histograms (Fig. 5).

Zircon grains from the gabbroic enclave sample (18STP01-1) are dominated by the euhedral shapes and ranged in size from 50 to $100 \mu \mathrm{m}$ (Supplementary, Fig. S2). These zircons yielded $U$ concentrations ranging from 78 to $424 \mathrm{ppm}$ (excepted one grain with an extremely high value of $1114 \mathrm{ppm}$ ) and $\mathrm{Th} / \mathrm{U}$ ratios of 0.3 - 1.9 (Table 2). A total of 49 spots were analyzed, and 38 of them yielded a mean ${ }^{206} \mathrm{~Pb} /{ }^{238} \mathrm{U}$ age of $4.1 \pm 0.3 \mathrm{Ma}$ (Fig. 5). The CL images of a majority of the zircon grains from another andesitic breccia sample (18STP03-2) showed oscillatory bands and ranged in size from 50 to $200 \mu \mathrm{m}$ (Supplementary, Fig. S2). The U concentrations ranged from 153 to $362 \mathrm{ppm}$ and exhibited $\mathrm{Th} / \mathrm{U}$ ratios between 0.4 and 0.8 (Table 2). It (18STP03-2) was analyzed for its U-Pb ages on 52 zircon grains and 41 of them yielded a mean age of $4.5 \pm 0.2 \mathrm{Ma}$ (Fig. 5)

\subsection{Major Elements Compositions}

The four volcanic breccias from the ignimbrite of the 

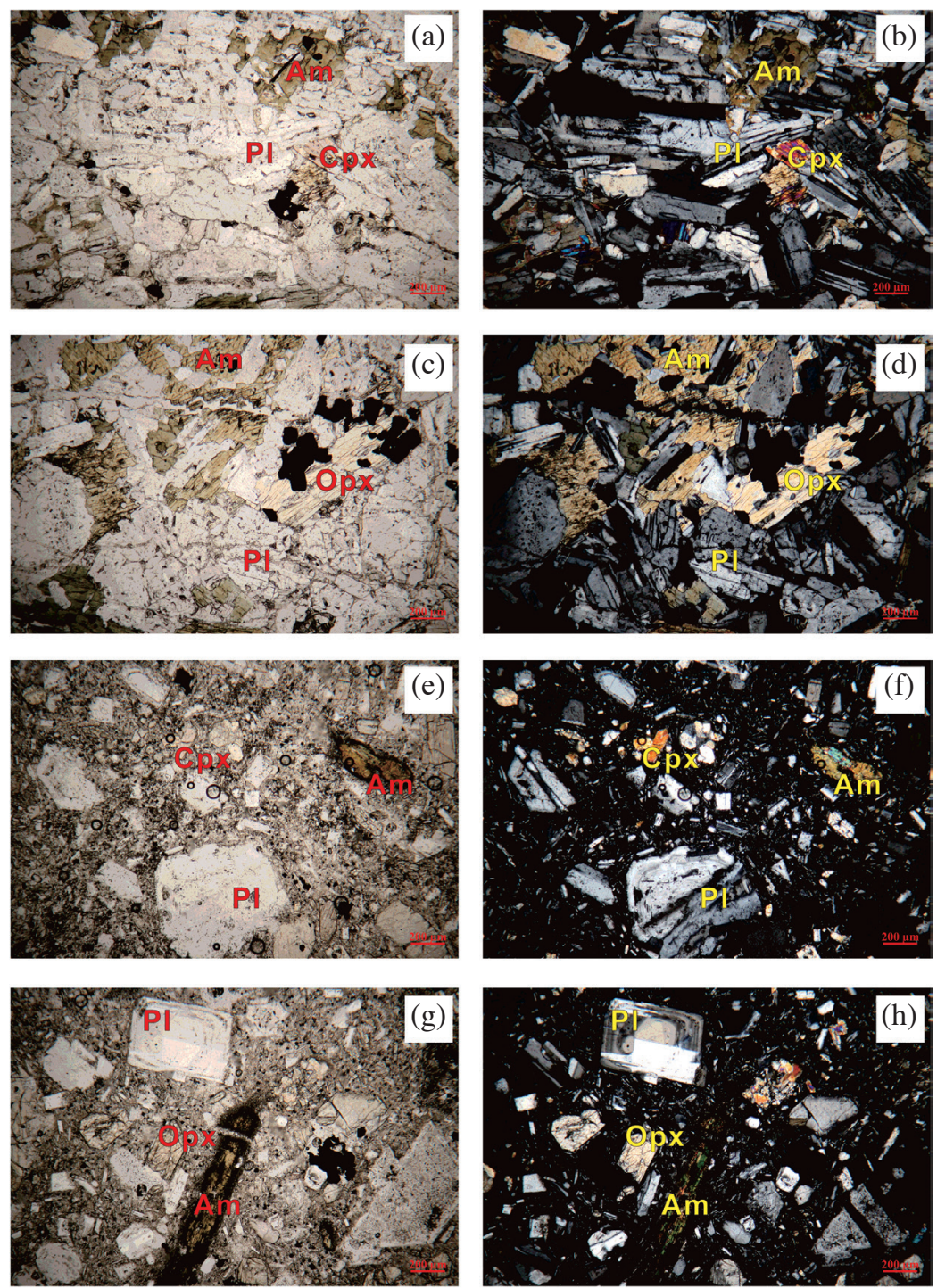

Fig. 4. Photomicrographs showing the texture under open- and cross-polarized light of (a) - (d) the gabbroic enclave (18STP01-1) and (e) - (h) the andesitic breccia $(18 \mathrm{STP} 02-1)$. Am = Amphibole, $\mathrm{Pl}=$ Plagioclase, $\mathrm{Cpx}=$ Clinopyroxene, Opx = Orthopyroxene.

Table 1. Petrographic modal analysis for the selected samples.

\begin{tabular}{|c|c|c|c|c|c|c|c|c|c|}
\hline \multirow{2}{*}{$\begin{array}{c}\text { Thin Section } \\
\text { No. }\end{array}$} & \multirow{2}{*}{ Lithology } & \multicolumn{5}{|c|}{ Mineral Portion (\%) } & \multirow{2}{*}{$\begin{array}{c}\text { Phenocrysts } \\
(\%)\end{array}$} & \multirow{2}{*}{$\begin{array}{c}\text { Groundmass } \\
(\%)\end{array}$} & \multirow{2}{*}{$\begin{array}{l}\text { Total } \\
\text { Counts }\end{array}$} \\
\hline & & Plagioclase & Clinopyroxene & Orthopyroxene & Amphibole & Fe-Ti oxides & & & \\
\hline 18STP01-1 & Gabbroic enclave & 72.3 & 0.8 & 2.6 & 21.7 & 2.6 & - & - & 379 \\
\hline 18STP02-1 & Andesitic breccia & 73.2 & 9.6 & 11.6 & 3.5 & 2.0 & 60.2 & 39.8 & 329 \\
\hline
\end{tabular}




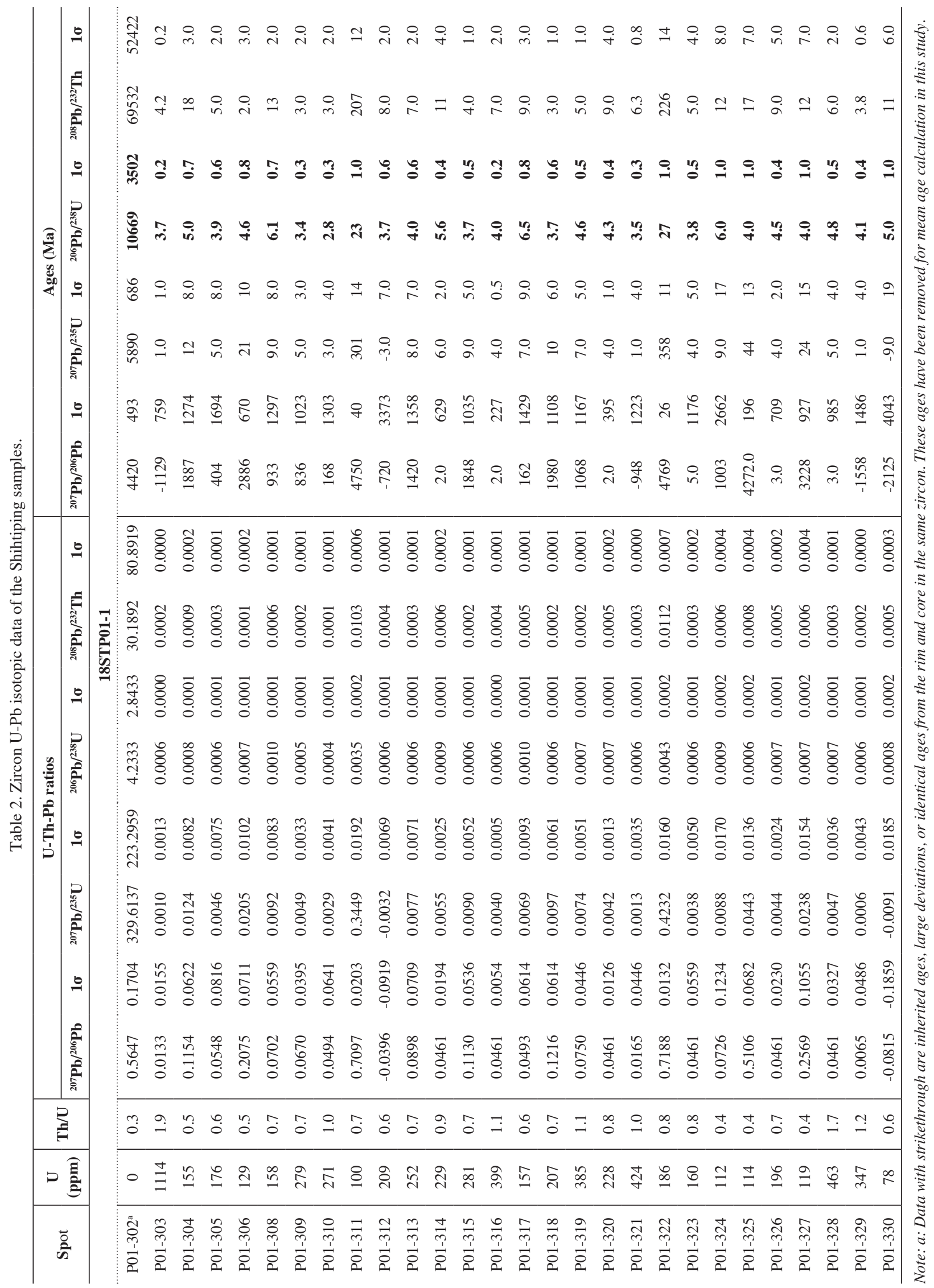




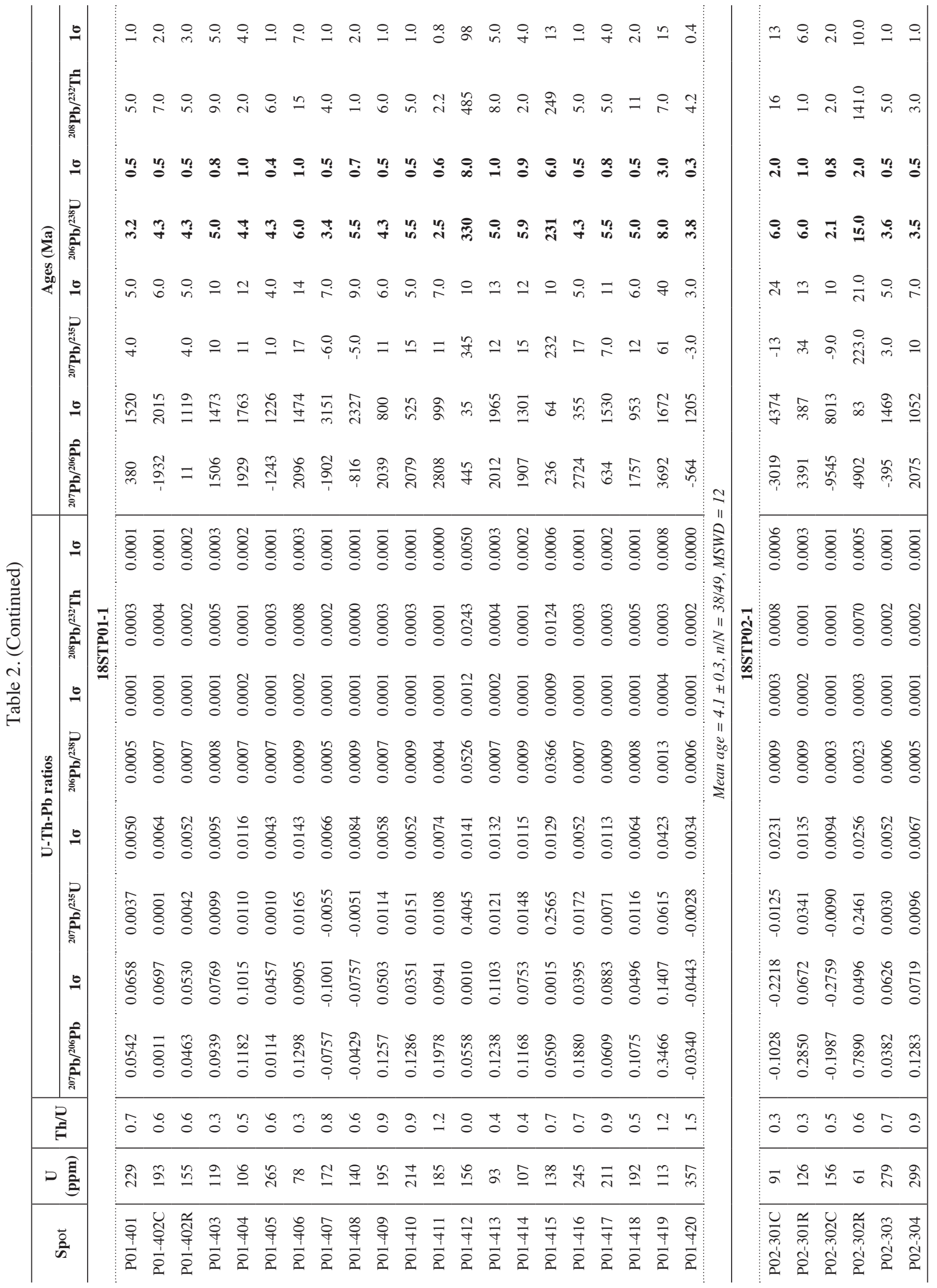




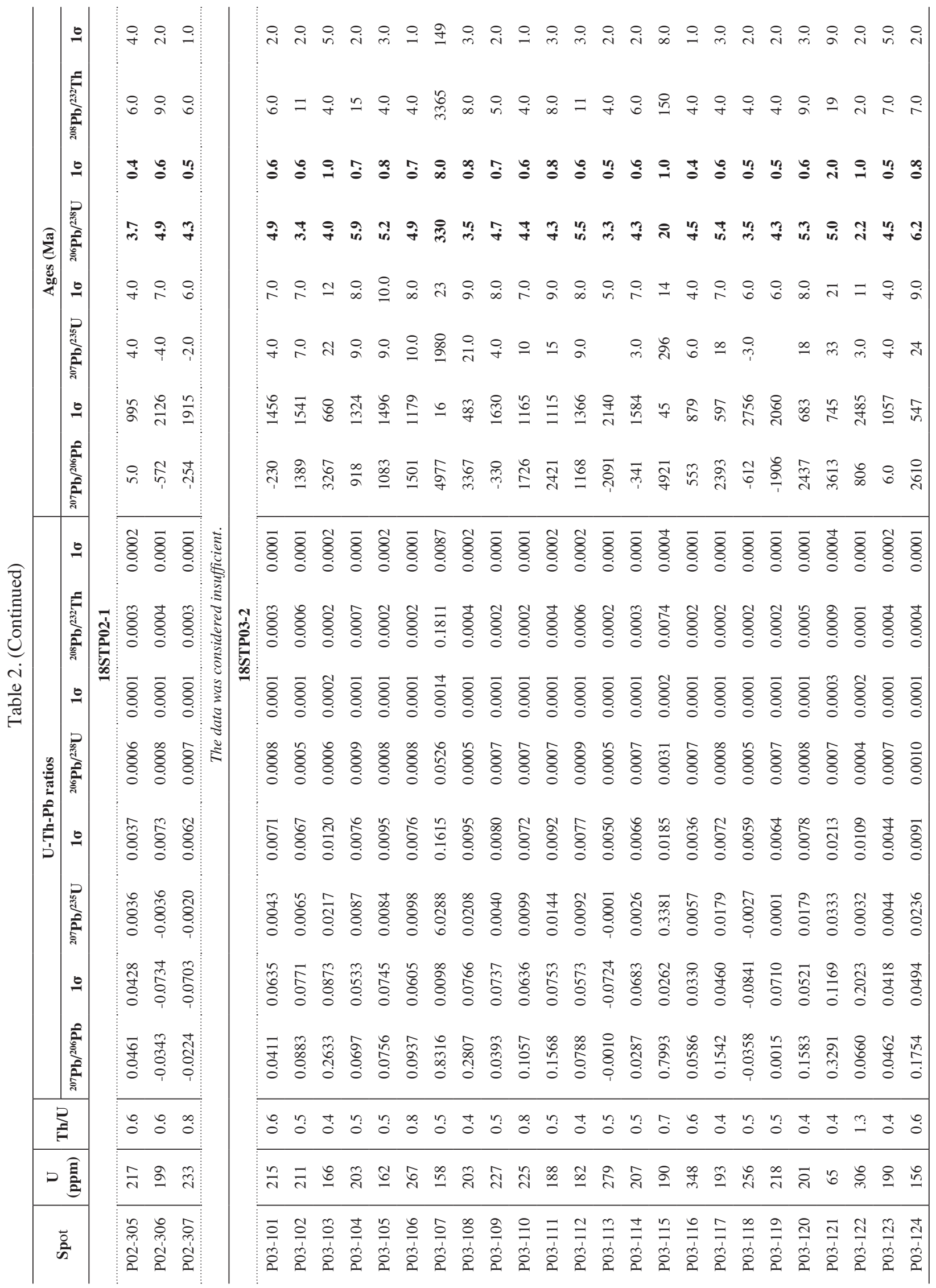




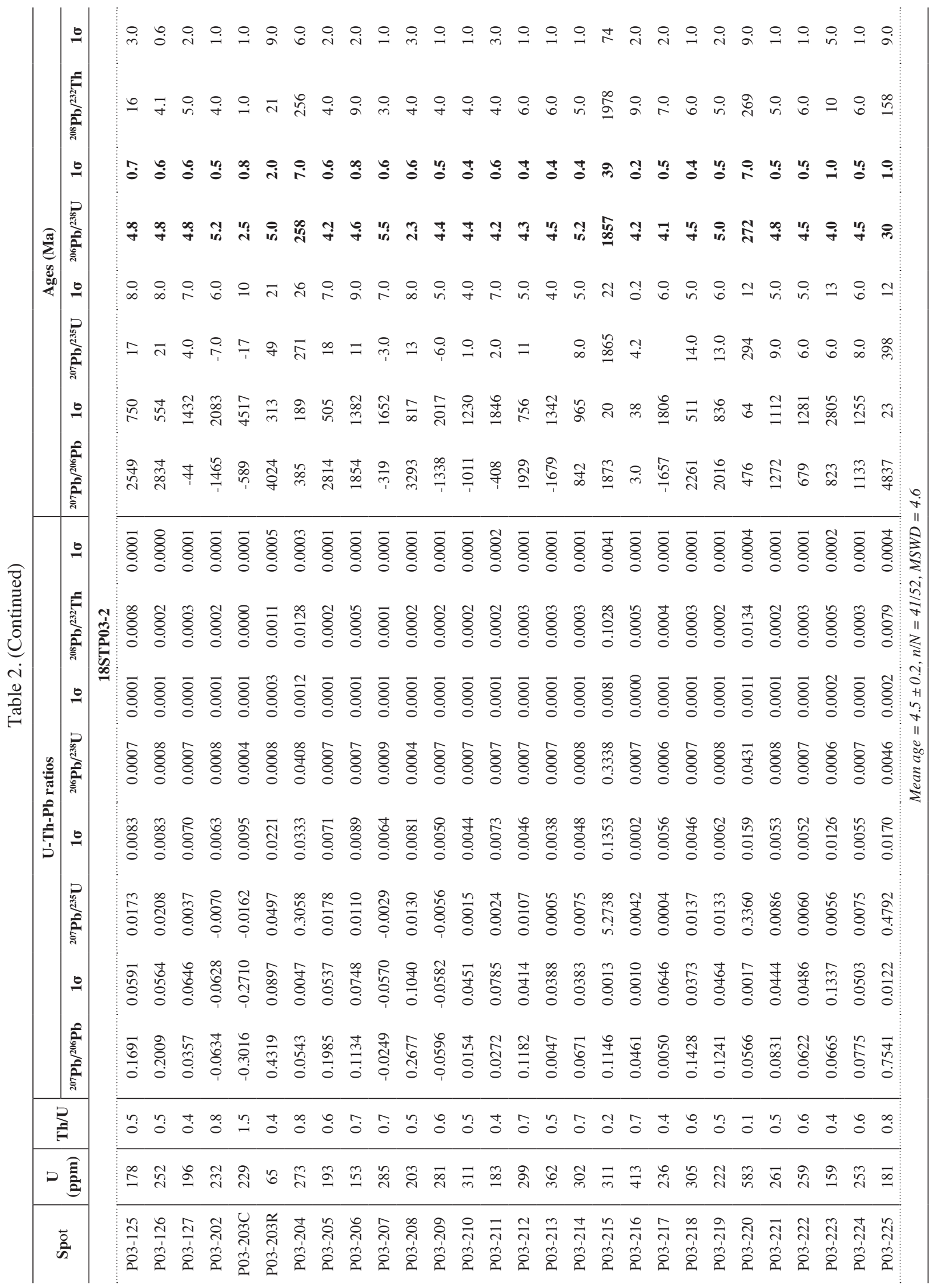



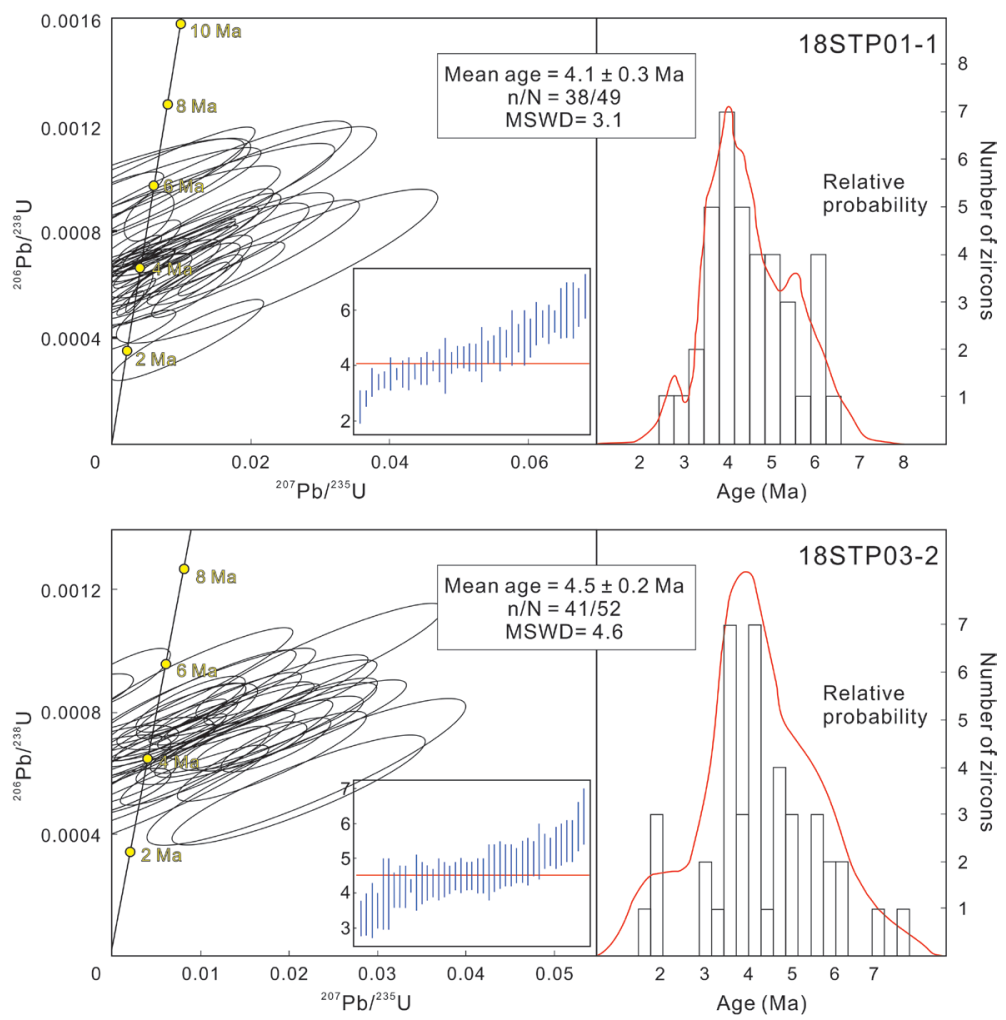

Fig. 5. Concordia diagrams, probabilistic histograms, and weighted averages of zircon U-Pb age results from the dated samples in the Shihtiping area.

Shihtiping area in Chimei volcano are basaltic andesites to andesites with $\mathrm{SiO}_{2}$ contents ranging between 53 to 58 wt.\% (Fig. 6 and Table 3), which reveal a medium-K calcalkaline series $\left(\mathrm{K}_{2} \mathrm{O}=0.7-1.2 \mathrm{wt} . \%\right)$ (Fig. 7). The gabbroic enclave with $\mathrm{SiO}_{2}$ content of approximately $48 \mathrm{wt} . \%$ shows low-K characteristics $\left(\mathrm{K}_{2} \mathrm{O}=0.2\right.$ wt.\%) (Fig. 7 and Table 3). Figures 6 and 7 also show the comparison of the compositions of volcanic rocks in the Chimei volcano and the whole CR from the previous studies (Lai et al. 2017, 2018). The white volcanic breccias (18STP02-1, 18STP032 , and 18STP04-1) contain higher $\mathrm{K}_{2} \mathrm{O}(>0.7$ wt. $\%), \mathrm{Na}_{2} \mathrm{O}$ (> 2.1 wt.\%), $\mathrm{SiO}_{2}(>53.0$ wt.\%), and lower $\mathrm{MgO}(<4.3$ wt.\%), $\mathrm{Al}_{2} \mathrm{O}_{3}$ (<20.0 wt.\%), $\mathrm{CaO}(<7.8$ wt. $\%), \mathrm{TiO}_{2}(<$ 0.53 wt.\%); whereas, the gabbroic enclave is lower in $\mathrm{K}_{2} \mathrm{O}$ (0.2 wt. \%), $\mathrm{Na}_{2} \mathrm{O}$ (1.4 wt.\%), $\mathrm{SiO}_{2}$ (48.3 wt.\%), and higher in $\mathrm{MgO}$ (5.6 wt.\%), $\mathrm{Al}_{2} \mathrm{O}_{3}$ (23.1 wt.\%), $\mathrm{CaO}$ (11.8 wt.\%), and $\mathrm{TiO}_{2}(0.64$ wt.\%). Figure 8 shows the Haker diagrams of volcanic rock samples from the Chimei volcano and the whole CR, data from this study are marked in red, the other samples were published by Lai et al. $(2017,2018)$.

\subsection{Trace Elements Compositions}

All trace element data are listed in Table 3. Figure 9 shows the rare earth element (REE) diagram of the gabbro- ic enclave and andesitic breccias from this study, and also plots the data of andesitic bombs in ignimbrite (from the Shihtiping Tuff), black breccias (from the Shihmen Volcanic Breccia), and dykes and lava flows (from the Chimei Igneous Complex) in the Chimei volcano published by Lai et al. $(2017,2018)$. All samples were not accompanied by any Eu anomalies (Fig. 9). The REE pattern of the two lower volcanic sequences show flat trends, whereas those of the andesitic breccias and bombs in Shihtiping Tuff show a varying light rare earth element (LREE) enriched pattern. It is notable that the gabbroic enclave also shows moderately LREE-enriched patterns, and the heavy rare earth element (HREE) compositions were higher than those of all other samples (Fig. 9). In the primitive mantle-normalized trace element diagram, all samples were marked by significant enrichment in large ion lithophile elements (LILE, e.g., Cs, Rb, Ba, K, and $\mathrm{Sr}$ ) and $\mathrm{Pb}$. However, compositions of these elements in the andesitic breccias and bombs were an order of magnitude higher than the compositions in the two lower volcanic sequences and gabbroic enclave (Fig. 10). All samples show depletion of the high field strength elements (e.g., Ta, $\mathrm{Nb}$, and $\mathrm{Ti}$ ) as an island arc magmatism characteristic. The $\mathrm{Ba} / \mathrm{Nb}$ versus $\mathrm{La} /$ $\mathrm{Nb}$ diagram also shows that all samples were present in the arc volcanism area (Fig. 11a). 


\section{DISCUSSION}

\subsection{Geochemical and Geochronological Comparison of the Gabbroic Enclave and the Volcanic Sequences in Chimei Volcano}

Several previous studies (Chen 1975; Chen et al. 1990; Song 1990; Lai et al. 2017) recognized the volcanic rocks in the $\mathrm{CR}$ show geochemical variations in the volcanic sequences from bottom to top. Chimei volcano, located in the central part of the $\mathrm{CR}$, its volcanic sequences were completely exposed by anterior erosion (Song 1990; Lai and Song 2013). Here, we compare the geochemical variations and the dating results of the gabbroic enclave from the ignimbrite and the volcanic rocks from whole volcanic sequences in the Chimei volcano. In Figs. 6 to 8, one gabbroic enclave and four volcanic breccias from this study are marked in red squares and circles, respectively. Data from the previous studies are including four white bombs from the Shihtiping Tuff (marked by blue circles), six black breccias from the Shihmen Volcanic Breccia (marked by orange triangles), and six dykes and lava flows from the Chimei Igneous Complex (marked by green triangles).

According to Figs. 7 and 8, samples in the Chimei volcano show a magma differentiation trend as their $\mathrm{SiO}_{2}$ contents had a positive correlation with $\mathrm{K}_{2} \mathrm{O}$ and $\mathrm{Al}_{2} \mathrm{O}_{3}$ and a negative correlation with $\mathrm{MgO}, \mathrm{CaO}$, and $\mathrm{Fe}_{2} \mathrm{O}_{3}(\mathrm{~T})$. However, samples from the Shihtiping Tuff which belongs to the top volcanic sequence of this volcano show much more enriched in LREEs (Fig. 9) and incompatible elements (Fig. 10) than samples from the lower part of volcanic sequences, i.e., the Shihmen Volcanic Breccia and Chimei Igneous Complex. The increase in crustal contamination with time may cause these significant geochemical variations (Chen et al.
1990; Song 1990; Lai et al. 2017). Geochronologically, the zircon $\mathrm{U}-\mathrm{Pb}$ age of a dyke sample from the Chimei Igneous Complex in Chimei volcano was $\sim 9 \mathrm{Ma}$ (Shao et al. 2015) and can be as old as 15 to 16 Ma by zircon fission-track ages (Yang et al. 1988, 1995); the black breccia from Shihmen Volcanic Breccia was 5.5 Ma by K-Ar ages (Song 1990); and both of the groundmass ${ }^{40} \mathrm{Ar}-{ }^{39} \mathrm{Ar}$ (Lai et al. 2017) and zircon U-Pb (Lai et al. 2018) dating results show the white bombs in the Shihtiping Tuff were $\sim 4 \mathrm{Ma}$. Therefore, both geochemical and geochronological results show the magmatic process in Shihtiping Tuff is entirely different from the lower volcanic sequences in the Chimei volcano.

The gabbroic enclave sample shows lower $\mathrm{SiO}_{2}, \mathrm{~K}_{2} \mathrm{O}$, and incompatible element concentrations (Figs. 7 and 9) and higher contents in $\mathrm{MgO}, \mathrm{CaO}$, and $\mathrm{Fe}_{2} \mathrm{O}_{3}$ (Fig. 8) than other white breccias in the ignimbrite. These geochemical characteristics indicate the different magma mechanisms between the enclaves and andesites in the Shihtiping Tuff. However, the enrichment of LREEs, $\mathrm{Sr}$, and $\mathrm{Pb}$ shows the gabbroic enclave was not formed with the lower volcanic sequences (Figs. 9 and 10). The most conclusive evidence is both the gabbroic enclave and white breccias have the same age $4 \mathrm{Ma}$ (Fig. 5) and younger than samples from the lower volcanic sequences.

The plot of $\mathrm{La} / \mathrm{Yb}$ versus $\mathrm{La}$ and $\mathrm{V}$ versus $\mathrm{Rb}$ diagrams are shown in Figs. 11b and c, respectively. In these diagrams, we can find not only the significant difference of magma compositions between the Shihtiping Tuff and the lower volcanic sequences but also larger degrees of partial melting have affected the gabbroic enclave than the white breccias in ignimbrite. Because of the variation in trace element contents can result from the crustal contamination as well, further $\mathrm{Sr}-\mathrm{Nd}$ isotopes analysis of the gabbroic enclave

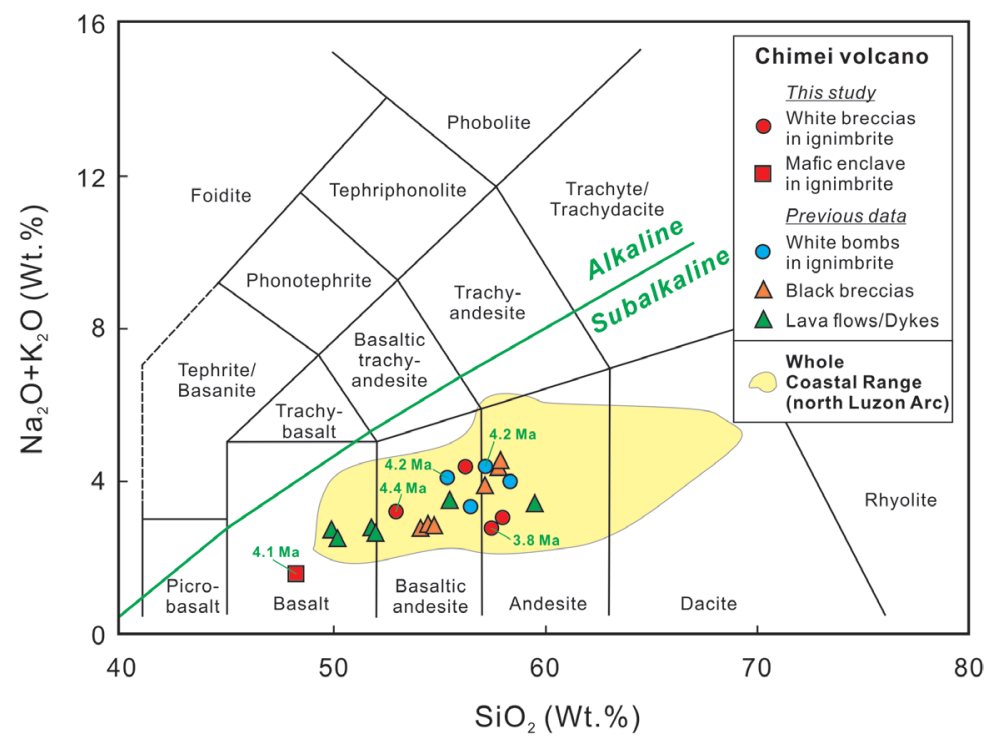

Fig. 6. Diagram of total alkali $\left(\mathrm{Na}_{2} \mathrm{O}+\mathrm{K}_{2} \mathrm{O}\right)$ versus $\mathrm{SiO}_{2}$ for the samples in the Chimei volcano and the whole Coastal Range (after Irvine and Baragar 1971; Le Maitre et al. 2002). Data from the previous studies were obtained from Lai et al. (2017, 2018) (Supplementary, Table S2). 


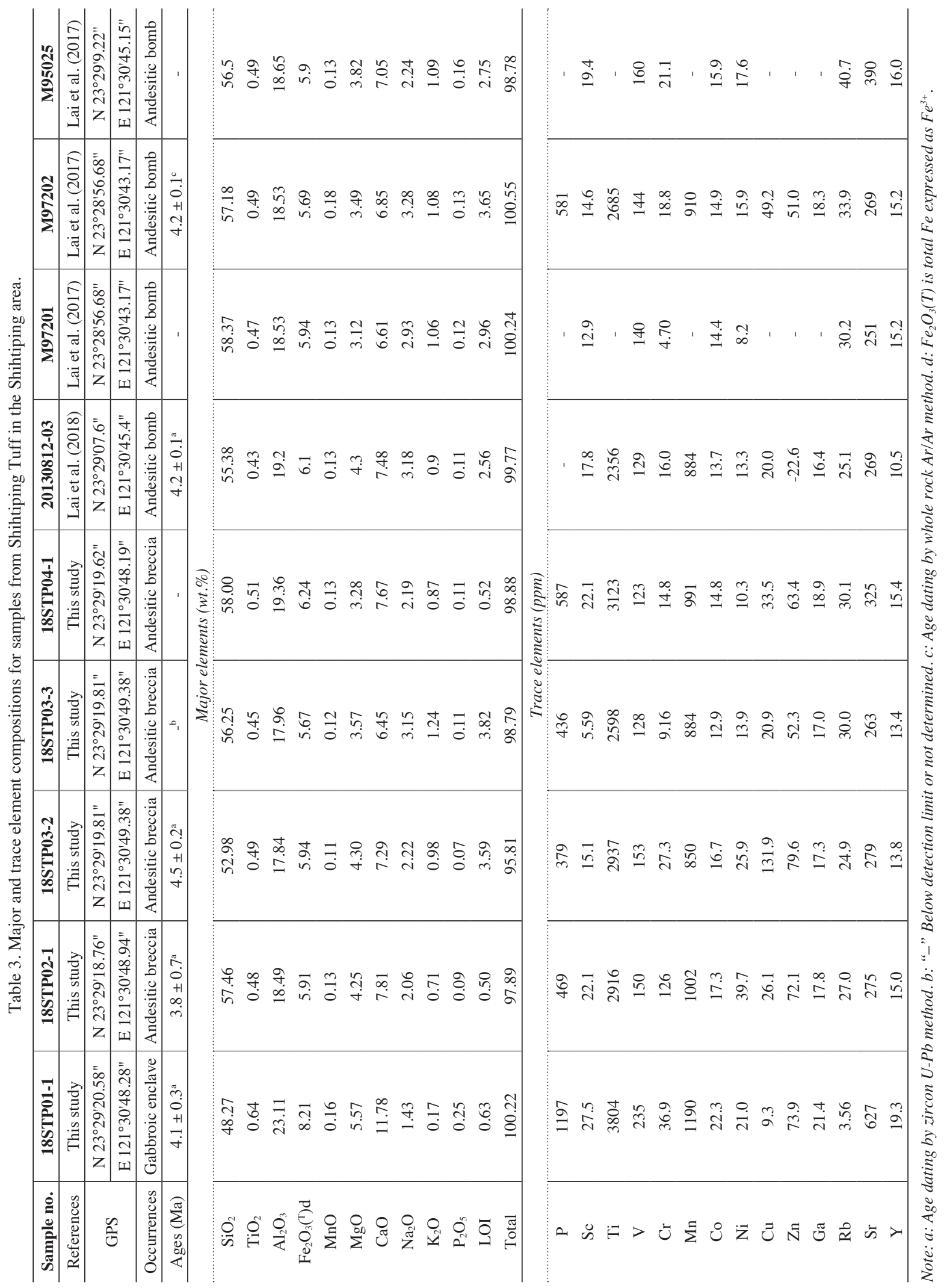




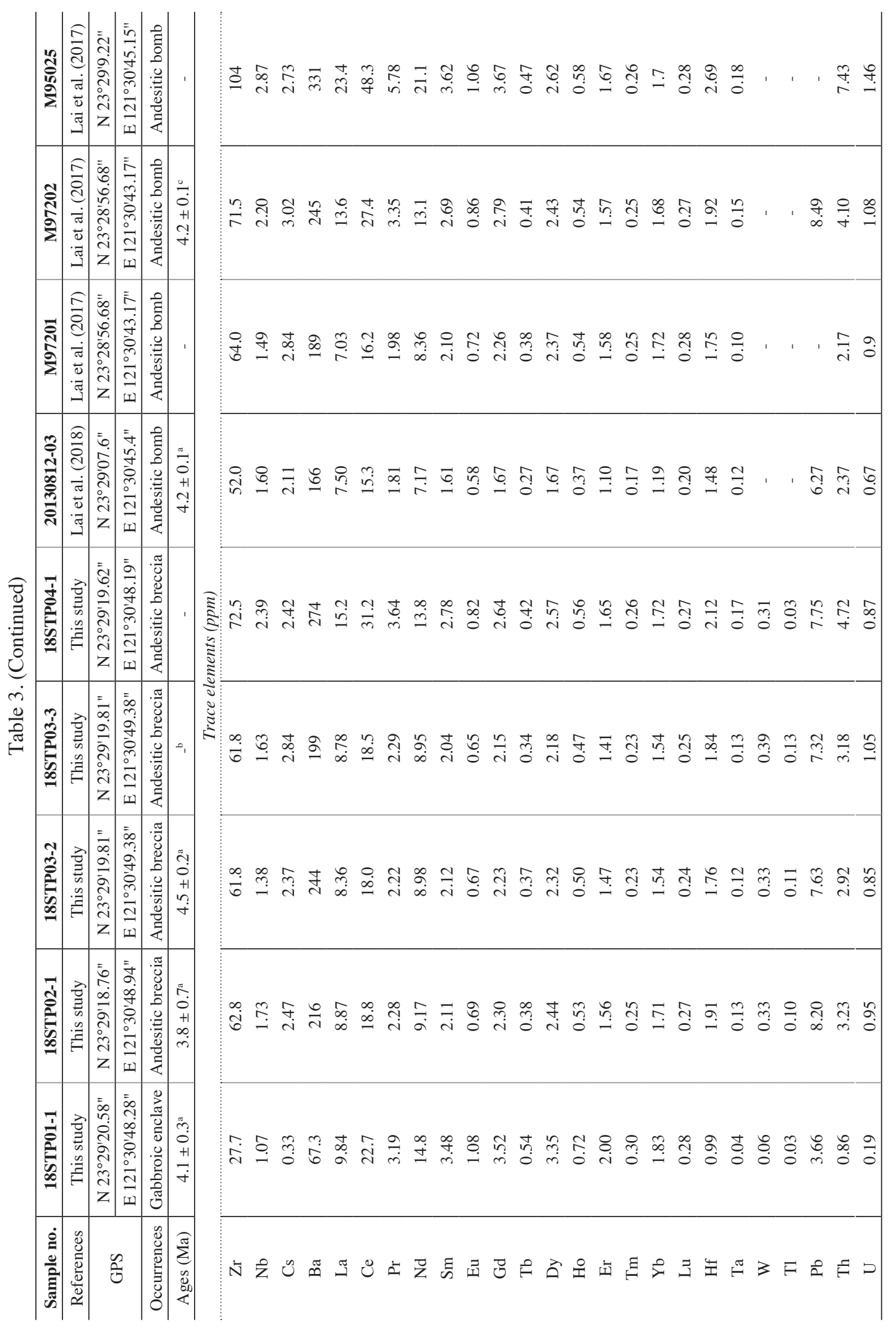




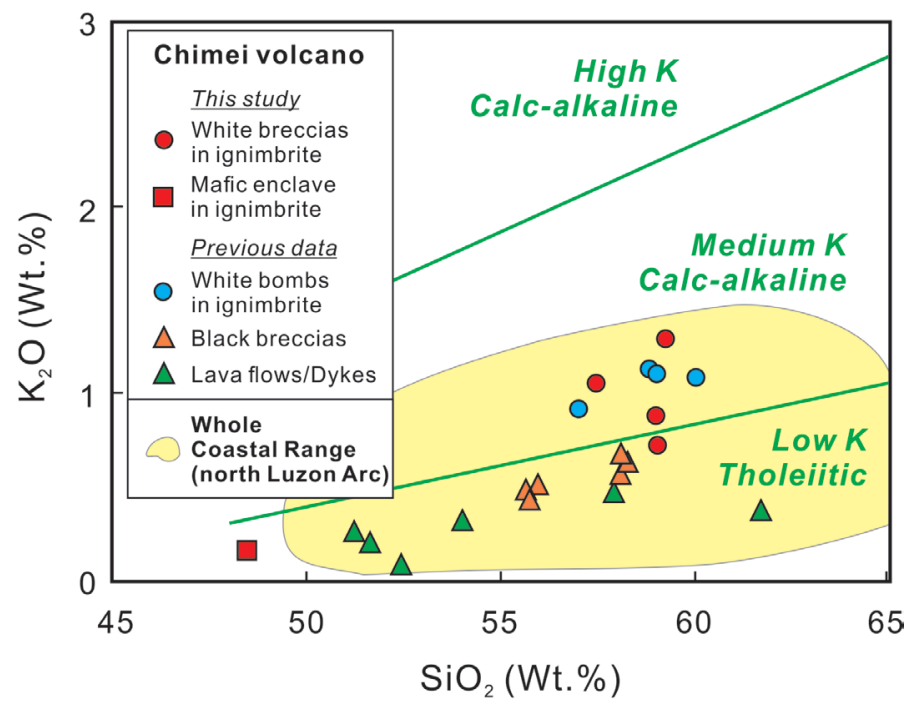

Fig. 7. Variation of $\mathrm{K}_{2} \mathrm{O}$ with $\mathrm{SiO}_{2}$ for the samples in the Chimei volcano and the whole Coastal Range. The classification was after Gill (1981). Data from the previous studies were obtained from Lai et al. $(2017,2018)$ (Supplementary, Table S2).
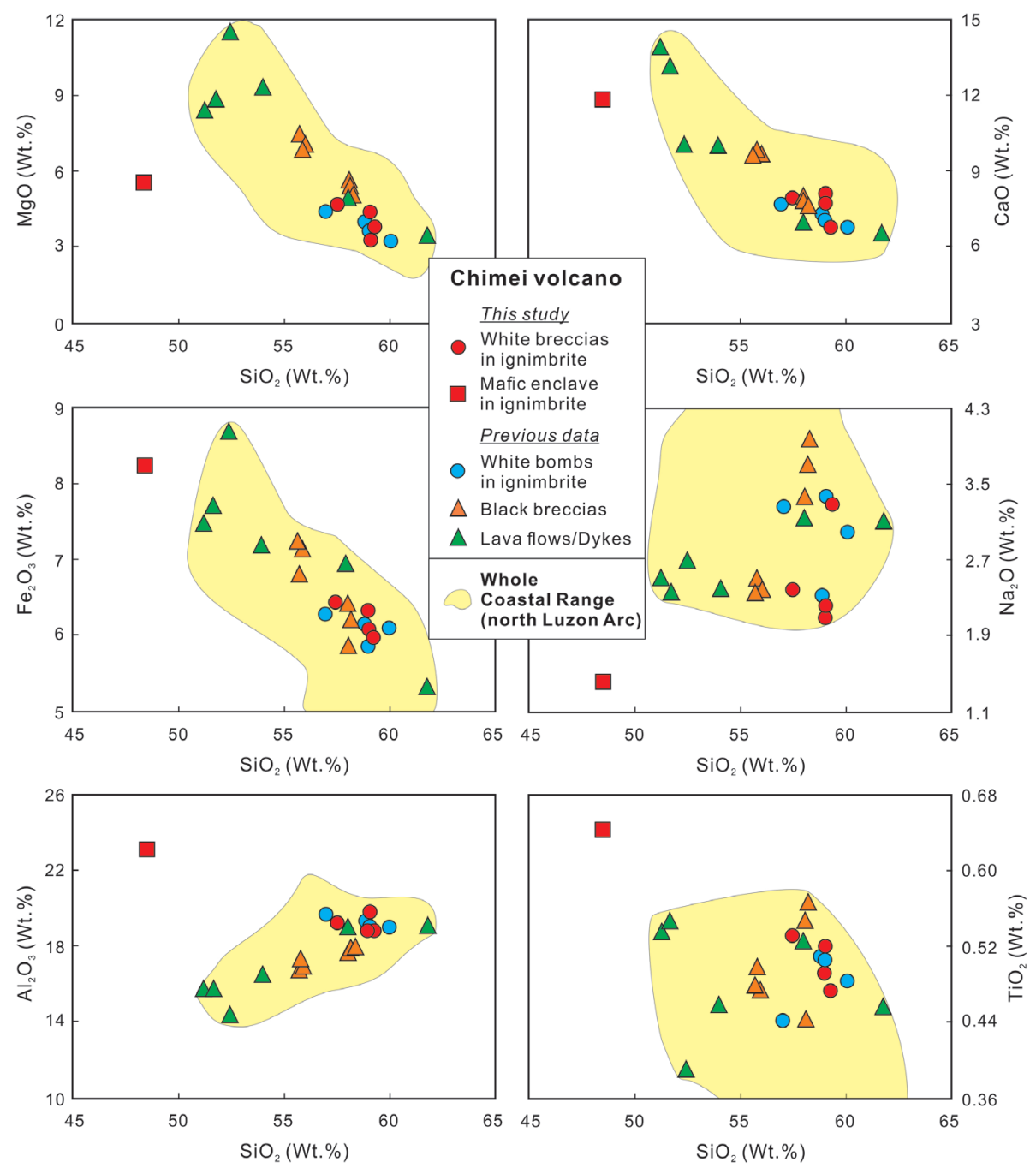

Fig. 8. Plots of major elements versus $\mathrm{SiO}_{2}$ for the samples in the Chimei volcano and the whole Coastal Range. Data from the previous studies were obtained from Lai et al. $(2017,2018)$ (Supplementary, Table S2). 


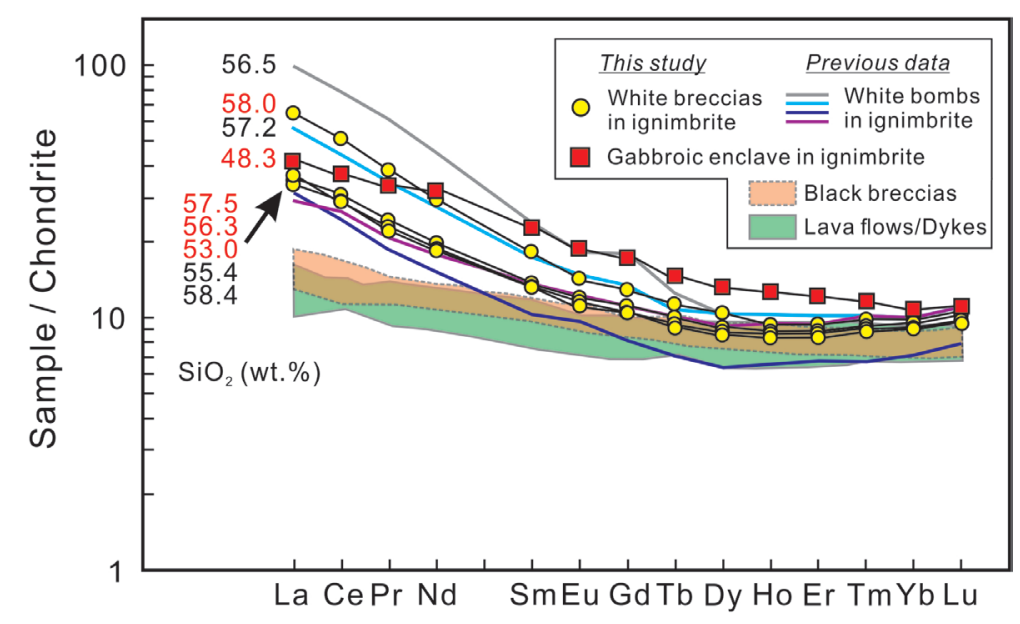

Fig. 9 Chondrite normalized REE variation diagrams for the samples in the Chimei volcano. The numbers show their silicate contents, and the words in red are data from this study. Data from the previous studies were obtained from Lai et al. (2017, 2018) (Supplementary, Table S2). Chondrite normalizing values were obtained from Sun and McDonough (1989).

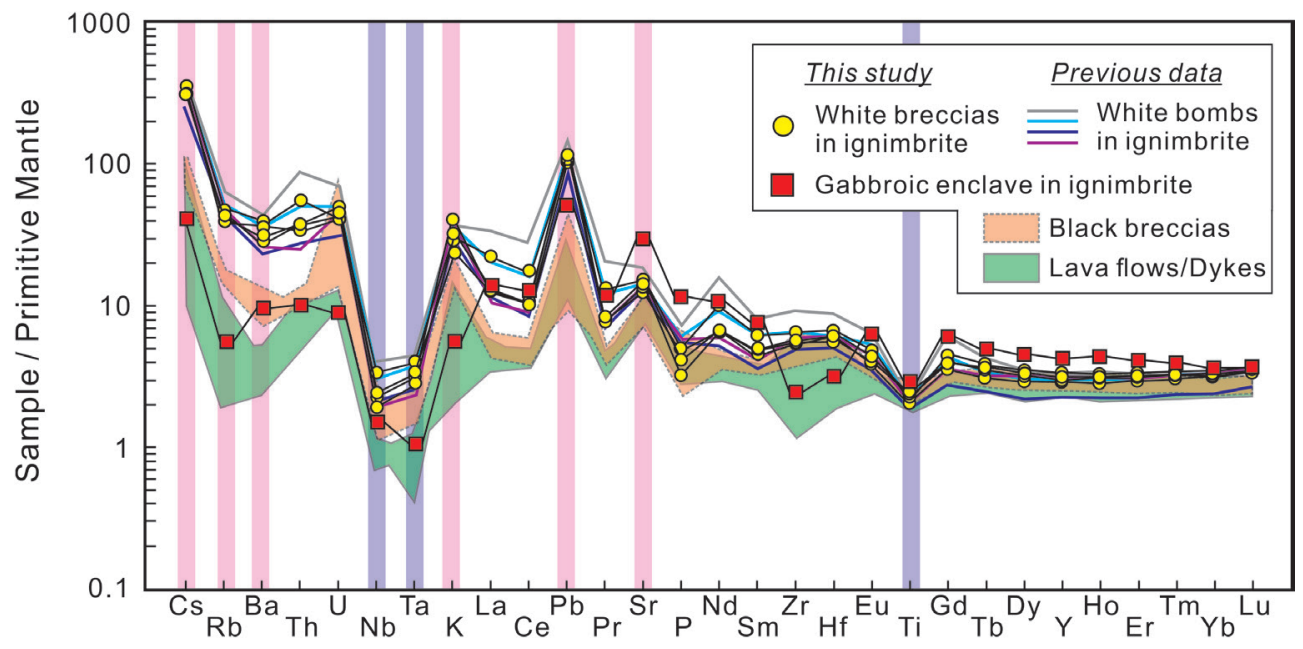

Fig. 10. Primitive mantle normalized trace element variations for the samples in the Chimei volcano. Data from the previous studies were obtained from Lai et al. $(2017,2018)$ (Supplementary, Table S2). Primitive mantle normalizing values were obtained from Sun and McDonough (1989). 
(a)

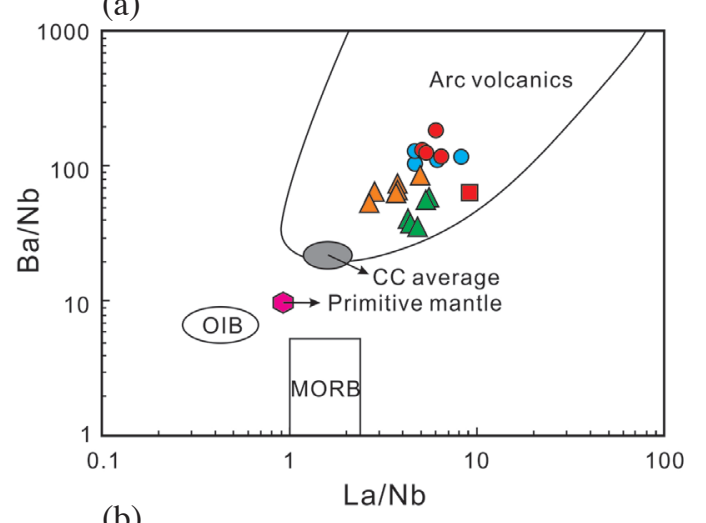

(b)

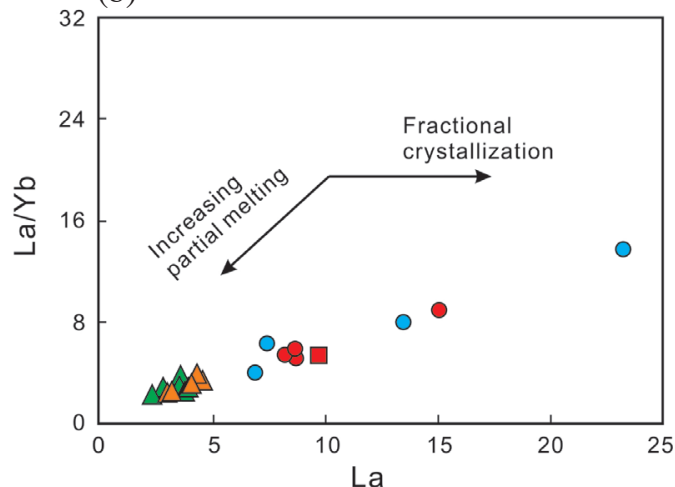

(c)

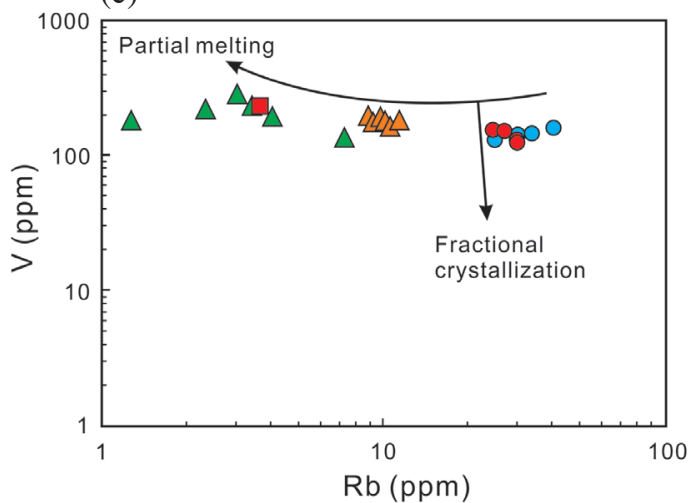

(d)

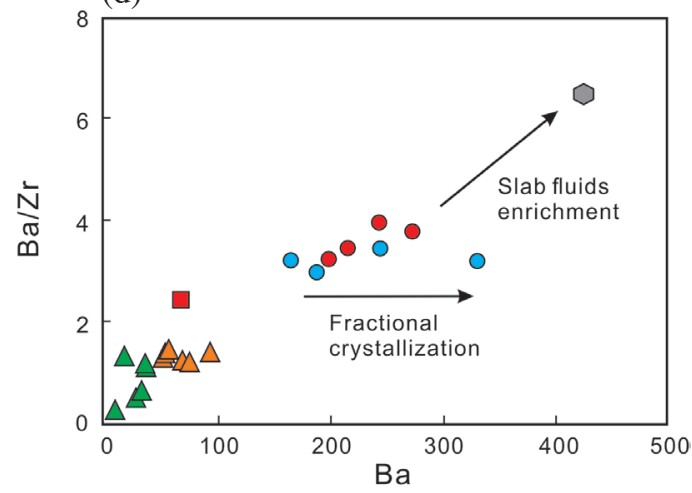

(e)

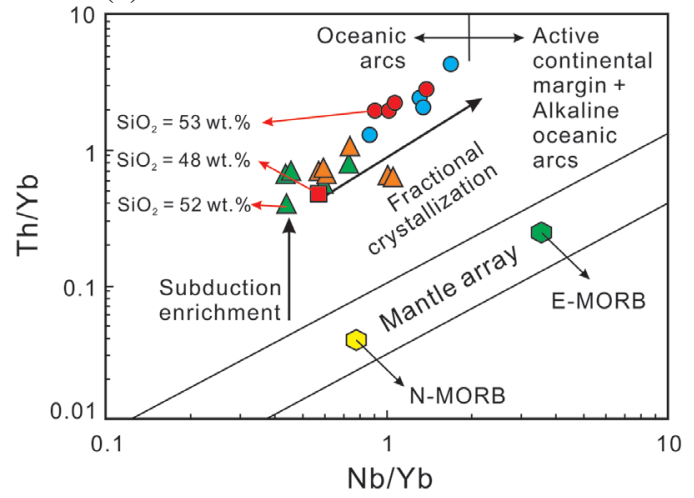

Fig. 11. Selected geochemical variation diagrams for the samples in the Chimei volcano. Data from the previous studies were obtained from Lai et al. (2017, 2018) (Supplementary, Table S2). (a) Ba/Nb versus La/Nb diagram after Jahn et al. (1999) and references therein. (b) La/Yb versus La diagram. (c) The incompatible element $V$ versus compatible element $\mathrm{Rb}$ (ppm) diagram. (d) $\mathrm{Ba} / \mathrm{Zr}$ versus $\mathrm{Ba}$ (ppm) diagram. The gray hexagon shows the highest Ba content in the Coastal Range from Lai et al. (2017), and (e) Th/Yb versus Nb/Yb diagram after Pearce (2008) and references therein. 
would be needed. Moreover, the lower concentrations of incompatible elements in the gabbroic enclave than the white breccias can be due to the same reason (Figs. 7 and 10). Figures $11 \mathrm{~d}$ and e show the geochemical data in white breccias affected predominantly by fractional crystallization based on the plots of $\mathrm{Ba} / \mathrm{Zr}$ versus $\mathrm{Ba}$ and $\mathrm{Th} / \mathrm{Yb}$ versus $\mathrm{Nb} / \mathrm{Yb}$, respectively. In Fig. 11d, the signal of slab fluid enrichment present in the upper volcanic sequence in Chimei volcano is also suggested for all volcanics in the NLA by McDermott et al. (1993). In Fig. 11e, the basaltic samples from the enclave $\left(\mathrm{SiO}_{2}=48\right.$ wt. $\left.\%\right)$, white breccia $\left(\mathrm{SiO}_{2}=\right.$ 53 wt.\%), and the lower volcanics $\left(\mathrm{SiO}_{2}=52\right.$ wt.\%) show different characteristics of their magmas, and the white breccia show significant variations of fractional crystallization. According to the plots of REEs, white breccias show fractional crystallization trends and are separable from the lower volcanic sequences (Supplementary, Fig. S3). However, the gabbroic enclave sample is out of the regression line of white breccias.

\subsection{The Origin of Gabbroic Enclave in the Shihtiping Ignimbrite}

Mafic enclaves commonly occur in the volcanic sequences or coexist within the plutonic rocks, and although rare, could have occurred with the ignimbrite sequence (Elburg 1996; Barbey et al. 2005; Bardelli et al. 2020). In arc-related volcanic rocks, the mafic enclaves are incorporated into the subsequent magma from the earlier stages of magmatism, such as the intrusive bodies or the cumulates in magma chamber/reservoir (Bacon 1986; Clynne 1999; Coombs et al. 2003; Browne et al. 2006; Martin et al. 2006; Morgavi et al. 2013; Hernando et al. 2016; Plail et al. 2018). In the NLA, the mafic enclaves may have been trapped from two ways of magmatism. The first was during the initial eruptive stage of the volcanic island, i.e., the root zone of the volcanic island. The second way would be as cumulates from the shallow reservoir or magma chamber.

Several previous studies have described the evolution of volcanoes and magmas in the NLA (Chen et al. 1990; Defant et al. 1990; McDermott et al. 1993; Fourcade et al. 1994; Yang et al. 1996; Song and Lo 2002; Lai et al. 2008, 2017; Lai and Song 2013). According to these, the NLA grew from a related mafic composition shown in the lower volcanic sequences (Lai and Song 2013; Lai et al. 2017). In this study, the gabbroic enclave coexists with the intermediate ignimbrites. This mafic enclave could be caught when the intermediate magma arose and passed through the lower sequences. Nevertheless, the composition of the gabbroic enclave in this study was out of the variation range of the entire CR (Figs. 6 to 10) and the difference in ages of the gabbroic enclave and volcanic rocks from the lower sequences of NLA is important for identification as mentioned above. These show that the gabbroic enclave does not originate from the lower sequences of this island arc.

Our dating results show that both the gabbroic enclave and andesitic volcanic breccias/bombs formed at approximately 4 Ma (Fig. 5 and Table 3) (Lai et al. 2017; and this study). According to the geochemical data, partial melting affects the composition of the gabbroic enclave more than from fractional crystallization, which was observed in the andesitic breccias and bombs samples (Figs. 11b to e). We suggest that the gabbroic enclave and andesitic breccias in the ignimbrites were formed from different magmas passed through the same magma reservoir. The former was formed from earlier magma cooled to form the gabbroic wall rock; the latter was formed from subsequent magma rose and fractionated in this reservoir. The amphibole-rich cumulates were formed in the magma reservoir and caused the different mineral assemblages between the gabbroic wall rock and andesitic magma (Table 1), and also made the HREE content in the enclave significantly higher than all the other andesitic breccias (Fig. 9). Gabbroic enclave could form when the fractionated magma rose in conduit and assimilated with the wall rocks.

\subsection{Three Sub-Stages Magmatic Processes at 4 Ma}

According to the dating results, the Shihtiping Tuff erupted at $\sim 4 \mathrm{Ma}$ (Lai et al. 2017, 2018) when the volcanic island (Chimei volcano) had grown up in a subaerial environment (Song and Lo 2002; Lai and Song 2013). Consistent with previous work, zircon U-Pb ages in both the gabbroic enclave and andesitic breccias in the ignimbrite are also at $\sim 4 \mathrm{Ma}$ (Fig. 5). Here, we suggest such a three sub-stages magmatic processes model at $\sim 4 \mathrm{Ma}$ based on the geochemical characteristics described above.

At the first sub-stage, a mafic magma $\left(\mathrm{SiO}_{2} \sim 48 \mathrm{wt} . \%\right)$ generated by higher degrees of partial melting from the magma source with moderate LREE enrichment and relatively lower LILE concentrations accumulated in the shallow magma reservoir (Figs. 8, 9, 10, and 12a). Then, the outer portion of the magma reservoir cooled down to form the gabbroic wall rocks (Fig. 12a). The second sub-stage at $\sim 4$ Ma occurred subsequently. Magma generated by lower degrees of partial melting from the magma source rose and injected into this magma reservoir (Fig. 12b). The magma stayed in this reservoir and fractionated to produce the intermediate magma $\left(\mathrm{SiO}_{2}=53-58 \mathrm{wt} . \%\right)$ with relatively higher LREE enrichment and LILE concentrations. Thereafter, magma recharged and triggered the intermediate magma to erupt. The intermediate magma assimilated with the gabbroic wall rocks when it flowed through the conduit (Fig. 11c). Magma mixing and mingling events can happen in the shallow reservoir and evidence of it is present in the field occurrences (Fig. $3 \mathrm{~m}$ ). This andesitic magma finally erupted on the top of Shihtiping Tuff and formed ignimbrite including andesitic breccias/bombs and gabbroic enclaves (Fig. 11c). 


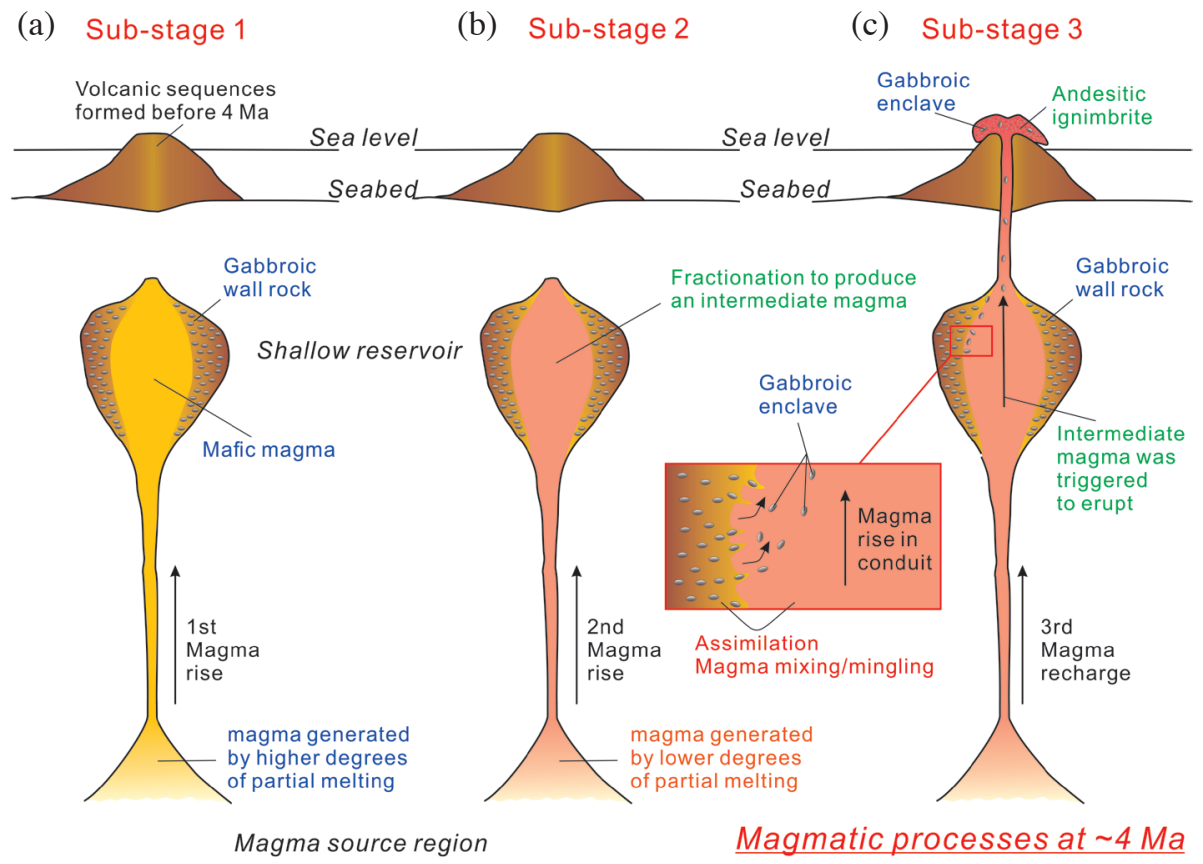

Fig. 12. Schematic models for the three sub-stages of magmatism at about $4 \mathrm{Ma}$. All mafic and intermediate materials are marked in blue and green, respectively. (a) At sub-stage 1, mafic magma generated by higher degrees of partial melting rose to the shallow reservoir and cooled sown to from the gabbroic wall rock. (b) At sub-stage 2, a magma generated by lower degrees of partial melting is injected into the magma reservoir and fractionated to produce an intermediate magma in this magma reservoir. (c) At the final sub-stage, the recharged magma rose and triggered the intermediate magma assimilated with the gabbroic wall rock. Eventually, the intermediate magma erupted to form ignimbrite and contained andesitic breccias/ bombs and coexisted with the gabbroic enclave.

\subsection{The Record of the Youngest Eruption in the CR}

The Shihtiping Tuff is the top volcanic sequence in the Tuluanshan Formation (Song and Lo 2002; Lai and Song 2013) and the volcanic rocks in this sequence can be considered as the youngest magmatism in the CR, northern part of the NLA. Several studies have estimated ages using different dating methods for this sequence from individual volcanoes in the $\mathrm{CR}$ and yielded ages ranging from 4.2 to 8.5 Ma (Song 1990; Lo et al. 1994; Lai et al. 2017, 2018). In this study, both the gabbroic enclave and the andesitic ignimbrite were found to have erupted at $\sim 4 \mathrm{Ma}$. Yang et al. (1995) published a fission track dating work in the CR and estimated the age of a lava flow sample from the Wushihpi area as approximately 2 - $3 \mathrm{Ma}$. In addition to this, they also estimated the age of a thin tuff layer in the sedimentary formation (<3.35 Ma, Chen and Wang 1988) from the Tungho area as 1.5 Ma (Chen et al. 1992; Yang et al. 1995). However, the later ${ }^{40} \mathrm{Ar}-{ }^{39} \mathrm{Ar}$ dating result of the volcanic block in Wushihpi revealed an age of approximately $5.4 \mathrm{Ma}$ (Lo et al. 1994), and after comparing the petrography and dating studies with those of the Lutao volcanic island on the sea, Yang et al. (1995) suggested that the 1.5 Ma tuff layer erupted from the Lutao Island, and not from the volcanoes in the CR. The evidence shows that the youngest eruption in the CR might be no younger than 4 Ma.

\section{CONCLUSIONS}

The field occurrences, petrography, geochronology and geochemistry studies of the gabbroic enclave and andesitic breccias and bombs from the Shihtiping ignimbrite lead us to the following conclusions:

(1) The zircon U-Pb dating results show that at approximately $4 \mathrm{Ma}$, the gabbroic enclave had the same age as the andesitic breccias in the ignimbrite, suggesting that a mafic shallow intrusion coexisted with the intermediate magma eruption.

(2) The geochemical variations in the gabbroic enclave and the andesitic breccias and bombs in the ignimbrite represent the island arc magmatic characteristics, and belong to similar magmatic processes of the NLA.

(3) Geochemical compositions of major and trace elements show that the gabbroic enclave was from a magma generated by higher degrees of partial melting. It shows lower concentrations of $\mathrm{SiO}_{2}, \mathrm{~K}_{2} \mathrm{O}$, and incompatible elements, and higher $\mathrm{CaO}, \mathrm{MgO}$, and $\mathrm{TiO}_{2}$ compositions than those of the andesitic rocks within the ignimbrite. Geochemical evidence also shows that crystal fractionation dominantly controlled the andesitic magma compositions.

(4) We identified three magmatic sub-stages in the youngest eruption of the CR in this study. First, the basaltic 
magma generated by higher degrees of partial melting rose to form a shallow reservoir in which the gabbroic wall rocks were formed around it. Second, the magma generated by lower degrees of partial melting is injected into this reservoir and fractionated to produce the intermediate magma. Third, the magma recharged to trigger the assimilation between the intermediate magma and the gabbroic wall rocks. The intermediate magma eventually erupted to form the andesitic ignimbrite and contained the gabbroic enclaves inside.

Acknowledgements We thank C.-H. Hung, Allie Honda, Y.-J. Hsin, and C.-H. Chen for help with experiments, and W.-Y. Hsia for her miscellaneous assistance. We want to express sincere appreciation to Prof. Sun-Lin Chung for his valuable comments on our manuscript. Furthermore, we thank the editor and anonymous reviewers for their insightful comments and suggestions. This study was financially supported by the MOST grants \#108-2116-M-003-005 and \#109-2116-M-003-005 to Y.-M. Lai.

\section{REFERENCES}

Andersen, T., 2002: Correction of common lead in U-Pb analyses that do not report ${ }^{204} \mathrm{~Pb}$. Chem. Geol., 192, 5979, doi: 10.1016/s0009-2541(02)00195-x. [Link]

Arvin, M., S. Dargahi, and A. A. Babaei, 2004: Mafic microgranular enclave swarms in the Chenar granitoid stock, NW of Kerman, Iran: Evidence for magma mingling. J. Asian Earth Sci., 24, 105-113, doi: 10.1016/j. jseaes.2003.09.004. [Link]

Bacon, C. R., 1986: Magmatic inclusions in silicic and intermediate volcanic rocks. J. Geophys. Res., 91, 60916112, doi: 10.1029/JB091iB06p06091. [Link]

Bacon, C. R. and J. Metz, 1984: Magmatic inclusions in rhyolites, contaminated basalts, and compositional zonation beneath the Coso volcanic field, California. Contrib. Mineral. Petrol., 85, 346-365, doi: 10.1007/ BF01150292. [Link]

Barbarin, B. and J. Didier, 1991: Conclusions: Enclaves and granite petrology. In: Didier, J. and B. Barbarin (Eds.), Enclaves and Granite Petrology, Elsevier, Amsterdam, 545-549.

Barbey, P., D. Ayalew, and G. Yirgu, 2005: Insight into the origin of gabbro-dioritic cumulophyric aggregates from silicic ignimbrites: $\mathrm{Sr}$ and Ba zoning profiles of plagioclase phenocrysts from Oligocene Ethiopian Plateau rhyolites. Contrib. Mineral. Petrol., 149, 233245, doi: 10.1007/s00410-004-0647-2. [Link]

Bardelli, L., M. Arnosio, W. Báez, N. Suzaño, R. Becchio, J. Viramonte, E. Bustos, and E. Bertea, 2020: Multibanded pumice in the Campo de la Piedra Pómez rhyolitic ignimbrite (Southern Puna Plateau): Pre-eruptive physical and chemical interactions between mafic and rhyolitic melts. J. South Am. Earth Sci., 101, 102616, doi: 10.1016/j.jsames.2020.102616. [Link]

Biq, C., 1972: Dual-trench structure in the Taiwan-Luzon region. Proc. Geol. Soc. China, 15, 65-75.

Bowin, C., R. S. Lu, C.-S. Lee, and H. Schouten, 1978: Plate convergence and accretion in Taiwan-Luzon region. AAPG Bull., 62, 1645-1672, doi: 10.1306/C1EA526016C9-11D7-8645000102C1865D. [Link]

Browne, B. L., J. C. Eichelberger, L. C. Patino, T. A. Vogel, J. Dehn, K. Uto, and H. Hoshizumi, 2006: Generation of porphyritic and equigranular mafic enclaves during magma recharge events at Unzen Volcano, Japan. $J$. Petrol., 47, 301-328, doi: 10.1093/petrology/egi076. [Link]

Chappell, B. W., A. J. R. White, and D. Wyborn, 1987: The importance of residual source material (Restite) in granite petrogenesis. J. Petrol., 28, 1111-1138, doi: 10.1093/petrology/28.6.1111. [Link]

Chen, J.-C., 1975: Geochemistry of andesites from the Coastal Range, Eastern Taiwan. Proc. Geol. Soc. China, 18, 73-88.

Chen, C.-H., Y.-N. Shieh, T. Lee, C.-H. Chen, and S. A. Mertzman, 1990: Nd-Sr-O isotopic evidence for source contamination and an unusual mantle component under Luzon Arc. Geochim. Cosmochim. Acta, 54, 24732483, doi: 10.1016/0016-7037(90)90234-C. [Link]

Chen, C.-H., T.-Y. Yang, R.-L. Tien, and T. Lee, 1992: Eruption ages of north Luzon Arc (Taiwan): Based on fission-track dating. Acta Geol. Taiwan., 30, 149-156.

Chen, W.-S. and Y. Wang, 1988: The Plio-Pleistocene basin development in the Coastal Range of Taiwan. Acta Geol. Taiwan., 26, 37-56.

Chiu, H.-Y., S.-L. Chung, F.-Y. Wu, D. Liu, Y.-H. Liang, I.-J. Lin, Y. Iizuka, L.-W. Xie, Y. Wang, and M.-F. Chu, 2009: Zircon U-Pb and Hf isotopic constraints from eastern Transhimalayan batholiths on the precollisional magmatic and tectonic evolution in southern Tibet. Tectonophysics, 477, 3-19, doi: 10.1016/j.tecto.2009.02.034. [Link]

Chiu, H.-Y., S.-L. Chung, M. H. Zarrinkoub, S. S. Mohammadi, M. M. Khatib, and Y. Iizuka, 2013: Zircon U-Pb age constraints from Iran on the magmatic evolution related to Neotethyan subduction and $\mathrm{Za}$ gros orogeny. Lithos, 162-163, 70-87, doi: 10.1016/j. lithos.2013.01.006. [Link]

Clynne, M. A., 1999: A complex magma mixing origin for rocks erupted in 1915, Lassen Peak, California. J. Petrol., 40, 105-132, doi: 10.1093/petroj/40.1.105. [Link]

Cole, J. W., J. A. Gamble, R. M. Burt, L. D. Carroll, and D. Shelley, 2001: Mixing and mingling in the evolution of andesite-dacite magmas; Evidence from comagmatic plutonic enclaves, Taupo Volcanic Zone, New Zealand. Lithos, 59, 25-46, doi: 10.1016/S00244937(01)00056-1. [Link] 
Coombs, M. L., J. C. Eichelberger, and M. J. Rutherford, 2003: Experimental and textural constraints on mafic enclave formation in volcanic rocks. J. Volcanol. Geotherm. Res., 119, 125-144, doi: 10.1016/S03770273(02)00309-8. [Link]

Couch, S., R. S. J. Sparks, and M. R. Carroll, 2001: Mineral disequilibrium in lavas explained by convective selfmixing in open magma chambers. Nature, 411, $1037-$ 1039, doi: 10.1038/35082540. [Link]

Defant, M. J., R. C. Maury, J.-L. Joron, M. D. Feigenson, J. Leterrier, H. Bellon, D. Jacques, and M. Richard, 1990: The geochemistry and tectonic setting of the northern section of the Luzon arc (the Philippines and Taiwan). Tectonophysics, 183, 187-205, doi: 10.1016/00401951(90)90416-6. [Link]

Didier, J., 1973: Granites and their Enclaves: The Bearing of Enclaves on the Origin of Granites, Elsevier, Amsterdam, $393 \mathrm{pp}$.

Dorais, M. J., J. A. Whitney, and M. F. Roden, 1990: Origin of mafic enclaves in the Dinkey Creek pluton, central Sierra Nevada Batholith, California. J. Petrol., 31, 853-881, doi: 10.1093/petrology/31.4.853. [Link]

Eichelberger, J. C., 1980: Vesiculation of mafic magma during replenishment of silicic magma reservoirs. Nature, 288, 446-450, doi: 10.1038/288446a0. [Link]

Elburg, M. A., 1996: U-Pb ages and morphologies of zircon in microgranitoid enclaves and peraluminous host granite: Evidence for magma mingling. Contrib. Mineral. Petrol., 123, 177-189, doi: 10.1007/s004100050149. [Link]

Fourcade, S., R. C. Maury, M. J. Defant, and F. Mcdermott, 1994: Mantle metasomatic enrichment versus arc crust contamination in the Philippines: Oxygen isotope study of Batan ultramafic nodules and northern Luzon arc lavas. Chem. Geol., 114, 199-215, doi: 10.1016/00092541(94)90053-1. [Link]

Geng, W., X.-H. Zhang, and L. Huang, 2018: Arc-continent collision of the Coastal Range in Taiwan: Geochronological constraints from U-Pb ages of zircons. J. Mar. Syst., 180, 182-190, doi: 10.1016/j.jmarsys.2016.11.014. [Link]

Gill, J. B., 1981: Orogenic Andesites and Plate Tectonics, Springer, Berlin, Heidelberg, 392 pp, doi: 10.1007/9783-642-68012-0. [Link]

Griffin, W. L., W. J. Powell, N. J. Pearson, and S. Y. O'Reilly, 2008: GLITTER: Data reduction software for laser ablation ICP-MS. In: Sylvester, P. (Ed.), Laser Ablation ICP-MS in the Earth Sciences: Current Practices and Outstanding Issues, Mineralogical Association of Canada, Short Course Series, Volume 40, 308-311.

Hernando, I. R., I. A. Petrinovic, E. J. Llambías, L. D’Elia, P. D. González, and E. Aragón, 2016: The role of magma mixing and mafic recharge in the evolution of a back-arc quaternary caldera: The case of Payún Matrú, western Argentina. J. Volcanol. Geotherm. Res., 311, 150-169, doi: 10.1016/j.jvolgeores.2016.01.008. [Link]

Ho, C.-S., 1969: Geologic significance of potassium-argon ages of the Chimei igneous complex in Eastern Taiwan. Bull. Geol. Surv. Taiwan, 20, 63-74.

Irvine, T. N. and W. R. A. Baragar, 1971: A guide to the chemical classification of the common volcanic rocks. Can. J. Earth Sci., 8, 523-548, doi: 10.1139/e71-055. [Link]

Jackson, S. E., N. J. Pearson, W. L. Griffin, and E. A. Belousova, 2004: The application of laser ablation-inductively coupled plasma-mass spectrometry to in situ U-Pb zircon geochronology. Chem. Geol., 211, 47-69, doi: 10.1016/j.chemgeo.2004.06.017. [Link]

Jahn, B., F. Wu, C.-H. Lo, and C.-H. Tsai, 1999: Crustmantle interaction induced by deep subduction of the continental crust: Geochemical and $\mathrm{Sr}-\mathrm{Nd}$ isotopic evidence from post-collisional mafic-ultramafic intrusions of the northern Dabie complex, central China. Chem. Geol., 157, 119-146, doi: 10.1016/S00092541(98)00197-1. [Link]

Jochum, K. P., U. Nohl, K. Herwig, E. Lammel, B. Stoll, and A. W. Hofmann, 2005: GeoReM: A new geochemical database for reference materials and isotopic standards. Geostand. Geoanal. Res., 29, 333-338, doi: 10.1111/j.1751-908X.2005.tb00904.x. [Link]

Juang, W. S. and H. Bellon, 1984: The potassium-argon dating of andesites from Taiwan. Proc. Geol. Soc. China, 27, 86-100.

Karig, D. E., 1973: Plate convergence between the Philippines and the Ryukyu Islands. Mar. Geol., 14, 153168, doi: 10.1016/0025-3227(73)90025-X. [Link]

Lai, Y.-M. and S.-R. Song, 2013: The volcanoes of an oceanic arc from origin to destruction: A case from the northern Luzon Arc. J. Asian Earth Sci., 74, 97-112, doi: 10.1016/j.jseaes.2013.03.021. [Link]

Lai, Y.-M., S.-R. Song, and Y. Iizuka, 2008: Magma mingling in the Tungho area, Coastal Range of eastern Taiwan. J. Volcanol. Geotherm. Res., 178, 608-623, doi: 10.1016/j.jvolgeores.2008.05.020. [Link]

Lai, Y.-M., S.-R. Song, C.-H. Lo, T.-H. Lin, M.-F. Chu, and S.-L. Chung, 2017: Age, geochemical and isotopic variations in volcanic rocks from the Coastal Range of Taiwan: Implications for magma generation in the Northern Luzon Arc. Lithos, 272-273, 92-115, doi: 10.1016/j.lithos.2016.11.012. [Link]

Lai, Y .-M., M.-F. Chu, W.-S. Chen, W.-Y. Shao, H.-Y. Lee, and S.-L. Chung, 2018: Zircon U-Pb and Hf isotopic constraints on the magmatic evolution of the Northern Luzon Arc. Terr. Atmos. Ocean. Sci., 29, 149-186, doi: 10.3319/TAO.2017.08.29.01. [Link]

Le Maitre, R. W., A. Streckeisen, B. Zanettin, M. J. Le Bas, 
B. Bonin, and P. Bateman, 2002: Igneous Rocks: A Classification and Glossary of Terms: Recommendations of the International Union of Geological Sciences Subcommission on the Systematics of Igneous Rocks, 2nd Edition, Cambridge University Press, Cambridge, U.K., 236 pp, doi: 10.1017/CBO9780511535581. [Link]

Lin, I.-J., S.-L. Chung, C.-H. Chu, H.-Y. Lee, S. Gallet, G. Wu, J. Ji, and Y. Zhang, 2012: Geochemical and Sr$\mathrm{Nd}$ isotopic characteristics of Cretaceous to Paleocene granitoids and volcanic rocks, SE Tibet: Petrogenesis and tectonic implications. J. Asian Earth Sci., 53, 131150, doi: 10.1016/j.jseaes.2012.03.010. [Link]

Lo, C.-H., T. C. Onstott, C.-H. Chen, and T. Lee, 1994: An assessment of ${ }^{40} \mathrm{Ar} /{ }^{39} \mathrm{Ar}$ dating for the wholerock volcanic samples from the Luzon Arc near Taiwan. Chem. Geol., 114, 157-178, doi: 10.1016/00092541(94)90049-3. [Link]

Ludwig, K. R., 2008: User's manual for Isoplot 4.15. A Geochronological Toolkit for Microsoft Excel, Berkeley Geochronology Center, Special Publications, Berkeley, CA.

Martin, V. M., D. M. Pyle, and M. B. Holness, 2006: The role of crystal frameworks in the preservation of enclaves during magma mixing. Earth Planet. Sci. Lett., 248, 787-799, doi: 10.1016/j.eps1.2006.06.030. [Link]

Maury, R. C., J. Didier, and J. Lameyre, 1978: Comparative magma/xenolith relationships in some volcanic and plutonic rocks from the French Massif Central. Contrib. Mineral. Petrol., 66, 401-408, doi: 10.1007/ BF00403425. [Link]

McDermott, F., M. J. Defant, C. J. Hawkesworth, R. C. Maury, and J. L. Joron, 1993: Isotope and trace element evidence for three component mixing in the genesis of the North Luzon arc lavas (Philippines). Contrib. Mineral. Petrol., 113, 9-23, doi: 10.1007/BF00320828. [Link]

Morgavi, D., D. Perugini, C. P. De Campos, W. Ertel-Ingrisch, and D. B. Dingwell, 2013: Time evolution of chemical exchanges during mixing of rhyolitic and basaltic melts. Contrib. Mineral. Petrol., 166, 615-638, doi: 10.1007/s00410-013-0894-1. [Link]

Pearce, J. A., 2008: Geochemical fingerprinting of oceanic basalts with applications to ophiolite classification and the search for Archean oceanic crust. Lithos, 100, 1448, doi: 10.1016/j.lithos.2007.06.016. [Link]

Plail, M., M. Edmonds, A. W. Woods, J. Barclay, M. C. Humphreys, R. A. Herd, and T. Christopher, 2018: Mafic enclaves record syn-eruptive basalt intrusion and mixing. Earth Planet. Sci. Lett., 484, 30-40, doi: 10.1016/j.eps1.2017.11.033. [Link]

Richard, M., H. Bellon, R. C. Maury, E. Barrier, and W.S. Juang, 1986: Miocene to Recent calc-alkalic volcanism in eastern Taiwan: K-Ar ages and petrography. Tectonophysics, 125, 87-102, doi: 10.1016/0040-
1951(86)90008-9. [Link]

Shao, W.-Y., S.-L. Chung, W.-S. Chen, H.-Y. Lee, and L.W. Xie, 2015: Old continental zircons from a young oceanic arc, eastern Taiwan: Implications for Luzon subduction initiation and Asian accretionary orogeny. Geology, 43, 479-482, doi: 10.1130/g36499.1. [Link]

Sláma, J., J. Košler, D. J. Condon, J. L. Crowley, A. Gerdes, J. M. Hanchar, M. S. A. Horstwood, G. A. Morris, L. Nasdala, N. Norberg, U. Schaltegger, B. Schoene, M. N. Tubrett, and M. J. Whitehouse, 2008: Plešovice zircon - A new natural reference material for $\mathrm{U}-\mathrm{Pb}$ and Hf isotopic microanalysis. Chem. Geol., 249, 1-35, doi: 10.1016/j.chemgeo.2007.11.005. [Link]

Song, S.-R., 1990: A Study of the Volcanic Rocks in the Central Coastal Range of Eastern Taiwan and the Evolution of Volcanic Island Arc of the Northern Luzon Arc. Ph.D. Thesis, Institute of Geology, National Taiwan University, Taipei City, Taiwan, 251 pp. (in Chinese)

Song, S.-R. and H.-J. Lo, 1990: The stratigraphy of volcanic rocks and related rocks of Coastal Range, eastern Taiwan. Special Publication of the Central Geological Survey, 4, 261-270. (in Chinese with English abstract)

Song, S.-R. and H.-J. Lo, 2002: Lithofacies of volcanic rocks in the central Coastal Range, eastern Taiwan: Implications for island arc evolution. J. Asian Earth Sci., 21, 23-38, doi: 10.1016/S1367-9120(02)00003-2. [Link]

Streckeisen, A., 1976: To each plutonic rock its proper name. Earth-Sci. Rev., 12, 1-33, doi: 10.1016/00128252(76)90052-0. [Link]

Sun, S. and W. F. McDonough, 1989: Chemical and isotopic systematics of oceanic basalts: Implications for mantle composition and processes. Geol. Soc. Lond. Spec. Publ., 42, 313-345, doi: 10.1144/GSL. SP.1989.042.01.19. [Link]

Suppe, J., 1981: Mechanics of mountain building and metamorphism in Taiwan. Mem. Geol. Soc. China, 4, 67-89.

Suppe, J., 1984: Kinematics of arc-continent collision, flipping of subduction, and back-arc spreading near Taiwan. Mem. Geol. Soc. China, 6, 21-33.

Teng, L. S., 1990: Geotectonic evolution of late Cenozoic arc-continent collision in Taiwan. Tectonophysics, $\mathbf{1 8 3}$, 57-76, doi: 10.1016/0040-1951(90)90188-E. [Link]

Teng, L. S., W.-S. Chen, Y. Wang, S.-R. Song, and H.-J. Lo, 1988: Toward a comprehensive stratigraphic system of the Coastal Range, eastern Taiwan. Acta Geol. Taiwan., 26, 19-35.

Vernon, R. H., 1984: Microgranitoid enclaves in granites-globules of hybrid magma quenched in a plutonic environment. Nature, 309, 438-439, doi: 10.1038/309438a0. [Link]

Wiebe, R. A., 1994: Silicic magma chambers as traps for basaltic magmas: The Cadillac Mountain Intrusive 
Complex, Mount Desert Island, Maine. J. Geol., 102, 423-437, doi: 10.1086/629684. [Link]

Wiedenbeck, M., P. Allé, F. Corfu, W. L. Griffin, M. Meier, F. Oberli, A. V. Quadt, J. C. Roddick, and W. Spiegel, 1995: Three natural zircon standards for U-Th-Pb, Lu$\mathrm{Hf}$, trace element and REE analyses. Geostand. Geoanal. Res., 19, 1-23, doi: 10.1111/j.1751-908x.1995. tb00147.x. [Link]

Yang, T. F., 1992: Magma evolution of north Luzon Arc and the tectonic implication. Ph.D. Thesis, Institute of Geology, National Taiwan University, Taipei City, Taiwan, 476 pp. (in Chinese with English abstract)

Yang, T.F., T.-K. Liu, and C.-H. Chen, 1988: Thermal event records of the Chimei igneous complex: Constraint on the ages of magma activities and the structural implication based on fission track dating. Acta Geol. Taiwan., 26, 237-246.

Yang, T. F., J.-L. Tien, C.-H. Chen, T. Lee, and R. S. Punongbayan, 1995: Fission-track dating of volcanics in the northern part of the Taiwan-Luzon Arc: Eruption ages and evidence for crustal contamination. J. Southeast Asian Earth Sci., 11, 81-93, doi: 10.1016/07439547(94)00041-C. [Link]

Yang, T. F., T. Lee, C.-H. Chen, S.-N. Cheng, U. Knittel, R. S. Punongbayan, and A. R. Rasdas, 1996: A double island arc between Taiwan and Luzon: Consequence of ridge subduction. Tectonophysics, 258, 85-101, doi: 10.1016/0040-1951(95)00180-8. [Link] 